\title{
Be My Own Champion
}

\author{
Jing Zhang
}

\section{Interview with Ms. Le Xing and Her Teacher}

Le Xing, female, born in $1991 .{ }^{1}$ An orphan from the welfare center who lives in a foster ${ }^{2}$ family. Mild intellectual disability. Graduated from the School of Special Education in Pudong New District, Shanghai. In 2007 and 2015, she participated in the Special Olympics World Summer Games. She started working in 2010 with three previous jobs as working experience. She's now married, with a son.

Interviewees: Le Xing and Ms. Ying Wang (Le Xing's teacher)

Interviewer and writer: Jing Zhang

Interview dates: October 29 and December 6, 2016

Interview places: Starbucks in Pudong New District, Shanghai; Library of Pudong New District, Shanghai

\footnotetext{
${ }^{1}$ Le Xing is an orphan from a welfare center who grew up in a foster family. Since she currently has no contact with the foster family, the interview with her teacher replaces that with her foster parents in this case; during the interview, Le Xing was fired, thus no working observation is included.

${ }^{2}$ Fostering is a care system in which a minor supervised by civil administration department is placed in a family that meets relevant criteria through prescribed procedures. The Chinese civil administration authorities have long considered the best way to bring up orphans and abandoned children. In the 1990s, Beijing, Shanghai, Anhui, and other cities launched experimental family foster care. According to the Notice on Issuing the Interim Measures for the Management of Family Fosterage (Civil Affairs Department Doc [2003]No. 144), a foster family shall meet the following conditions: it shall have a registered permanent residence and a domicile in the place where the fosterage service organization is located; the living area for each family member shall not be less than the local living level per person after the fostered child moves in; it shall have a steady income, and the per capita income of the family members shall be in the middle of or above the local per capita income level; the major fosterer shall be not less than 30 but not more than 65 years old, with good health, corresponding ability and experience in child fostering, and education of a junior high school level (or an equal level) and above.
}

J. Zhang (凶)

East China Normal University, 3663 Zhongshan Bei Ro., Shanghai 200062, China

(C) The Author(s) 2020

W. P. Alford et al. (eds.), An Oral History of the Special Olympics

in China Volume 2, Economy and Social Inclusion,

https://doi.org/10.1007/978-981-15-5128-4_15 


\section{From the Welfare Center to a Foster Family}

\section{Q: When were you born?}

Xing: August 10, 1991. I was born an orphan and sent to a welfare center. Later, I came to live in my foster mother's family, together with an elder brother, who was 5 years older than me. They didn't know about my intellectual state at that time.

I was adopted because my foster mother heard news about fosterage and thought it would be better to find a playmate for my brother. But at that time, my foster father was against this idea, as no one had time to take care of an extra child. Also, both of them needed to work at that time, which meant it might be inconvenient and unsafe for me to stay at home. Anyway, after a long discussion with her husband, my foster mother finally persuaded him. She went to the welfare center with her friends who also wanted to adopt children when she was almost 50 . None of them heard about fosterage before, so they all wanted to have a try.

After I was adopted, my brother would sometimes look after me during summer vacation. But I was too little, feeling afraid of the new environment. If I didn't behave well, my brother would lock me in the room or inside the cupboard. That was horrible! Sometimes I felt upset, and when my brother thought he couldn't do anything with me, he would call my mother back.

Q: Did your foster parents treat you well?

Xing: My mother used to take me to her elder sister's home during vacation and cooked wonton or noodles for me, but not after I grew up. She gradually discovered that it was hard for me to learn things. Later, she separated from my father as she said he had affairs even before my fosterage. Coupled with some other tension later on, my mother finally changed the lock on the gate to keep my father out of the house.

When I came to this family, they already spent less time together, and my father left the home when they separated. Gradually, my contact with my father decreased, but not my brother, as he would visit Grandma near our home on the same road. I visited Grandma when I was little as well. The old house and the road weren't rebuilt back then.

After the divorce, my mother gradually grew grumpy. When she was in a good mood, she could still listen to me; otherwise, she would lose her temper and ask me to shut up if I talked too much or too directly. I'm bad at the art of talking. I can only be straightforward and tell the truth. So, I had quite a hard time. For most of the time, my brother, my mother, and I stayed at home, while my father seldom came back. He would quarrel with my mother due to some issues and me. Everything just got messed up. This made my mother annoyed.

Before I went to school, my parents thought I was obedient and would tell others that, "Well, my girl is really good. She can help us with housework." They indeed taught me about it. But as I grew up, seeing my abilities didn't develop as others, my mother was kind of...

Q: How did your mother treat you after you grew up?

Xing: When I was little, I lived in the Haiyang Village near to Shangnan Road School. I needed to take a bus to go to school, but my mother wouldn't give me the 
bus fare. She said, "You're on your own." Thus, in the morning, without money or a public transportation card, I could only be a ticket evader by sneaking onto the bus among taller adults to avoid being seen by the driver. In the afternoon, however, as the school ended early at around three, I couldn't use the morning trick. So, I would return on foot. On Fridays, if the classes ended early, my classmates might carry me on their bikes. Going to school was even harder than going to work at that time. I loved walking home with my classmates as I could walk and chat with them in the park or visit my classmates' homes. I told none of this to my mother. She didn't trust me; and I didn't want to talk about it.

My mother worked from Monday to Friday and returned later than I did. Sometimes, when she arrived home, she would ask me when I left school and why I didn't pick up the phone at home. In this case, I would lie to her. I was quite a natural liar. Besides, I got a bad habit, which was stealing money! It developed because I had no pocket money at all to go out to play sometimes. Fortunately, I knew where my mother hid her money. Then my mother noticed the loss of money, discovered that I was the thief soon after she asked me about it, and beat me many times. I didn't care about it, actually, as I really had no other solution. If I ever asked her for money, she would ask me what for, and refused to give it to me on the grounds that I was a student instead of staff. But seeing other friends already had mobile phones and everything, I felt quite upset.

When we got along, I once said, "Mom, I want a mobile phone." She would say, "Why? You're always at home, why would you need it?" This made me quite unhappy. As I had been quite poor, it was only after I started working that I got my first mobile phone, a keyboard Nokia, which was given to me by a colleague close to me. I changed to better phones afterwards gradually. My brother once bought a SIM card for me, but no phone. His phone was an old one made of bad material. I didn't like it, either.

While I was at home, I had nothing to do and couldn't watch TV. My mother would watch me doing things. It was really boring. I could never go out at night, nor could my classmates come to my home, except sneaking in when my mother was out.

It was not until I went to the vocational department after I finished my ninth grade that my mother provided me with living expenses and a transportation card with a monthly top-up of 50 yuan. After I started working, my salary was also in her control. I got pocket money occasionally.

My mother hated it when I talked with others, especially about my family. She felt awkward. She thought what I said was different from her words. In the end, she wouldn't allow me to say anything, even the phone number of my home. Unlike my situation, my brother got everything he ever wanted. This really annoyed me.

My mother was always like this. After turning 50, due to her menopause, bad relationship with her husband, and other issues, she became quite grumpy. Also, she regretted adopting me, always mentioning that how smart I was when I was adopted, how it became harder and harder for me to learn things, and how I grew up a liar. I was still at her home when I participated in Special Olympics for the first time. She showed no interest in my gold medal, but became extremely happy when I told 
her that she could go with me to receive a bonus from my school. Later, I suggested to her that we could save half of the bonus and buy a TV with the other half. She agreed. When I became a member of staff, she also kept my payroll card.

Actually, I thought she was really kind when she was in a good mood. She would also worry about me, talking with me about my future and my marriage, while I just replied, yeah, I know, I know. Otherwise, it was impossible to start a normal conversation. According to her, she wouldn't say things twice, the way other people treat and teach children. She was impatient and irritable.

Q: How did your mother educate you in your daily life?

Xing: Basically, there was no education and she thought I was a bad learner. She once said, "Even though I taught you once, you would forget by the next time." But you can learn simple things like cleaning the table, so that you can live on your own. She also taught me to do the cleaning. Therefore, I could take care of myself at an early age and knew how to wash my socks when I started to go to school. She was weird in that since I was little, she taught me to collect and wash the dishware and clean the table, but asked me to clearly separate the ones I used, and the ones they used. She seemed to express her repulsion. I didn't understand this until I grew up.

Q: How's your relationship with your foster mother now?

Xing: Now I don't live at her home. Previously, the welfare center provided us grown-ups with houses for rent. Mine was relatively far away in Puxi. This sparked some conflict. That is why I left.

Q: Ms. Ying Wang, do you know about Le Xing's foster family?

Teacher: The household registration of Le Xing is still with the welfare center. Her case is not adoption, but fosterage. In the past, our school was not free. All the tuition fee and insurance were reimbursed by the welfare center. According to the national policy, the welfare center shall provide foster families with monthly childcare expenses, while the children can experience family life. This amount of money could serve as a subsidy for some families, as there were a large number of middle-aged men who lost their jobs. Fosterage requires signing an agreement every year to make sure the family won't carry out physical punishment or abuse the children. There were many cases of fosterage in the same group with Le Xing, we had four or five cases as well, but now the numbers have declined. Normally, fosterage ends at the age of 18 , when the children are independent.

I remember that when Le Xing came to our school, she already went to the first grade. She was about 7 years old. She was fostered before that and the fosterage lasted for a total of 13 years.

Le Xing was an obedient and cute child. She had a difficult time growing up as the education model of her foster mother could go to extremes sometimes. But on the other hand, her mother also paid a lot of effort since she became a single mother after her divorce, and she had to raise her son and foster child. We've always told Le Xing that she should be grateful to her mother who gave her a happy childhood. Without her help and upbringing, you may end up living with other children in the welfare center. After all, the mother brought her the warmth of family life. I think Le Xing was always thankful. 
Of course, the relationship between parents and children is out of the control of the latter, let alone a special child. It requires the effort of both sides. Despite some issues gradually arising in the process, we wouldn't get to the bottom of it and judge. After all, Le Xing has become an independent adult with a family. She can integrate into the society. This is what we hope to see.

Le Xing is really grateful as she always informs her foster mother of her life, including when she found a job, had a boyfriend, and got married. Generally, she grew up smoothly despite some sad memories with her mother. But in my opinion, a home is at least better than the welfare center, right? So, Le Xing, don't carry a grudge against your mother. Someday when your mother gets old, I believe you should still go to visit her if she doesn't refuse it.

\section{Twelve Years of Happiness in Special Education School}

Q: When did you go to school?

Xing: I stayed in a small kindergarten next to my mother's previous company when I was very little for a short while. She would take me there on the way to work. At that time, she thought I was cute, and she loved taking me out.

After kindergarten, I needed to go to a primary school. During the entrance exam, when the teacher asked me what my name was and who brought me here, I performed badly. I either didn't respond, or I understood the question, but didn't answer correctly. So, I failed. Facing such a result, my mother replied nothing, but suggested I went to a special education school, where I started the first grade. Since then, my mother started treating me differently. I never asked her about my lessons, nor did I want her to teach me. I was afraid that she would scold me.

She used to take me to school on her way to work and pick me up after work. But since the third grade, I started being on my own. On Fridays when classes ended early, I would go shopping with my classmates to avoid going home so early. And I would lie to my mother about my whereabouts in case she wouldn't let me out. I always told her that I walked all the way home.

Q: Did your mother help you with your homework?

Xing: She didn't need to. Normally, I would finish it at school, or at home occasionally when I didn't have enough time at school. Teachers could answer my questions. There were also a lot of classmates who would help each other. My mother hardly did this. She didn't have the patience and she thought I was a bad learner.

Q: Did you get awards from your mother when you performed well?

Xing: Teachers would award and praise me and tell me I was great when I performed well. They knew I was not that good at studying, so they paid close attention to me and helped me a lot.

Q: How did the teachers help you?

Xing: Teachers were changed frequently. I've forgotten many of them. But starting from the sixth grade to the ninth, Ms. Zhu remained as our math teacher and the teacher in charge. She knew about my situation and cared about me a lot. I also 
performed well so that she wouldn't worry. By the way, there's also Ms. Shi. During the first grade, when we were seven or eight, she wanted to make us do some exercises in the morning to strengthen our body. She took me to the PE room, actually the gymnastics room, to test my flexibility. I thought it was okay since I was little at that time. From then on, we exercised every morning before class and we needed to learn gymnastics as well. All the teachers considered us as normal people. They even took us to performances outside the school.

Teacher: She came to our school at the first grade, when I didn't work here. Her hair was quite short back then, looking like a naughty tomboy. That's why she was always assigned the role of a boy in dancing. There were a lot of photos (introducing photos in the album). She also took part in many extracurricular activities and foreign exchange activities. This is Tim, chairman of the Special Olympics Committee ${ }^{3}$ (pointing at the photo).

Xing: My mother didn't want me to wear my hair in plaits and I didn't know how to do it, either. Thus, I just kept it short. I was super like a boy, you know. There aren't that many photos left, in which my face looks big. Now I think the person in the photo doesn't look like me.

Q: How was Le Xing's performance at school?

Teacher: She wasn't that good in math, but performed much better during classes of life skills, right? She can make delicious steamed buns, much more capable than me. At that time, she was also a member of the gymnastics team led by Ms. Shi and the dancing team led by Ms. Yang.

In our school, since our strength lies in Special Olympics sports, we can offer more opportunities to students for learning and exchanges with other organizations. This helps improve their social skills. Teachers also consider students as their own children and give particular care to students like Le Xing and Zhang who live in a special family environment. For example, teachers would give the students new clothes outgrown by their own children. While at school, Le Xing would love to call her teachers mother, like Ms. Shi, Ms. Jin, and Ms. Yang.

Teachers from the welfare center are also very kind, treating these children like their families. Before the children turned 18, the welfare center would hold annual parties. Teachers, especially Ms. Dong and Ms. Qiu, would also ask them about their lives, study, and health.

Xing: I call the teachers mother. For example, I call Ms. Liu "Mom Liu". After I finished junior middle school, I went to the vocational department, where I met Mom Liu. Even though I've graduated long ago, I always contact her and ask her how she's doing. I also ask about the situation of Mom Wang (Ms. Ying Wang) (laughing). During weekends while I was at school, Ms. Cai would take me home to play with her children. She also took me to many charity events.

A few days ago, Ms. Shi asked when I would bring the performance costume used in Special Olympics to school, so I went to school for that. She said sorry for making you to come simply for this. I said it was okay, it was nothing. I could help you as long as I was still able to. Transportation to school is convenient. It's either a short bus

${ }^{3}$ Mr. Timothy Shriver, chairman of Special Olympics International. 
ride, or my husband can take me and my child to school by driving an electro-mobile for half an hour. My teacher said my child looked a lot like my husband.

Q: How long did you study at Pudong Special Education School?

Xing: From the first grade to the ninth grade. Then I went on to learn pastry in the vocational department.

Teacher: She entered our school at the age of seven. First, she finished the nineyear compulsory education, then she went to the vocational department in our school for another 3 years of study. So, she stayed at our school for 12 years in total.

Xing: In the vocational department, we needed to choose the major ourselves. I didn't choose business since I was bad at math, nor did I like to deal with tablecloths as in the hotel management major. Pastry seemed to be better. I just needed to knead the dough. Now I've changed my job and I don't practice it at home, so my skills have become rusty.

Q: How about the relationship among classmates?

Xing: There were more than 20 classmates in a class. The number of boys and that of girls were close. In the fourth grade, based on the performance, teachers would regroup the students with around 15 people in one class. Then this arrangement would remain the same until the ninth grade. We grew up and studied together, all the way up to the fifth or sixth grade. After school, several classmates and I would always go to the park. Sometimes they might invite other classmates, including boys.

Among them, there was a girl who was my best friend. She was the same age as me, and she also seemed to come from a welfare center. She was really smart, moving to our school from a regular school after the first grade. We were so young that we always quarreled and fought with each other, even grabbing each other by the hair. Teachers would tell us not to do that again. Normally, we solved it between ourselves. She's also a mother now. As with other classmates, our relationship was just so-so. We just mind our own business as we grow up. Currently, I also get along well with another girl of the same age as me. There's something wrong with her feet, so basically, she doesn't go to work.

In addition, I used to be very close to another girl about the same age as me. She wasn't abandoned by her parents. During school days, if my mother found out I stole some money, she would go to the school and blame that girl as well, since the girl asked me to steal 100 yuan for her. Teachers would rebuke my mother for this, while after returning home, I would be blamed and beaten by my mother. But the lesson wasn't learned. I would steal again just a few days later. I guess I didn't know what I was doing at the age of 10 or 11 back then. I didn't hate that girl even with all the trouble. We cared about each other. Her mother, having been divorced, cared less about details, including her use of money. She was similar to her mother in this respect. Sometimes I lied to my mother, saying that I wouldn't go home but I actually lived at the girl's house, my mother didn't care about this at all. The girl took good care of me, allowing me to use her things, while I also treated her very well since I was born in August and she was about 4 months younger. We were like sisters.

Both of us practiced artistic gymnastics. We attended a competition in Shanghai in 2007 when we were in the ninth grade. She didn't win the gold medal, but she did 
win silver and bronze ones. She thought this was no big deal and she had nothing to do with Special Olympics. She even told Ms. Shi that she wouldn't participate anymore. After marriage, she said she wouldn't attend Special Olympics even if she was asked to. It was meaningless. Her in-laws disliked this as well. Besides, she wanted to hide from her husband's family that she once participated in Special Olympics and went to a special education school. But in my opinion, that's ridiculous. A fact always remains a fact. Anyway, she thinks she's the same as other normal kids with the same level of hands-on abilities. And in terms of reaction and intelligence, she always outperforms me.

Until the ninth grade, we were in the same class. But later in the vocational department, she chose the business major in the context of supermarkets and dealt with numbers. Sometimes I felt she looked down on me. When we texted each other, she would keep asking me something, hoping to get a clear answer even if I didn't want to talk about it. Upon graduation, we gradually drifted apart. Later, she married a rich man in our class who was a year younger than her and owned two houses. She says she also owns a house; thus, she has three houses altogether. I don't buy it at all! She loves to brag, I know that. She also says she lives well as a conductor on the bus, working together with her husband. Actually, she doesn't get the job by herself, but through her husband's network. She's fat now. I seldom contact her.

She's still my WeChat friend, though. Her baby is 1 year older than mine. She always talks about her husband and asks me about the usage of diapers and ways of saving money. Just like her mother. They're both good at careful calculation.

Q: Do you still remember how your days in class were?

Xing: When I was in grade three or four in the Shangnan campus, the most annoying moment was when my teacher of Chinese asked me to recite poems, keeping me in the classroom even after class or after school. Actually, I could read them and remember them for a while, but when the teacher asked us to recite poems in the classroom the same day we learned them, I was so nervous that I was unable to do it. When all the other classmates left school, I was still there, listening to the teacher explaining everything to me carefully. I was a little freaked out, but the teacher was quite patient, asking me to read the poem again and preparing to answer my questions. Most of the teachers knew that I was bad at reading and learning Chinese and math, while super-fast in practical tasks.

Normally I finished my homework in school. If I encountered difficulties when I did the homework at home, I could call the teachers or ask them or my classmates when I went to school the next day. We had moments of relaxation and periods of heavy course load. Before the final exam, teachers would urge you to study harder, ask you to do the review exam paper many times, and review the mistakes or learn the textbooks more carefully. But actually, the review paper was the same as the actual one. Sometimes teachers might also invite me to the office to do the test papers. I remember them saying, "Le Xing, you didn't do this part very well. This method didn't work. As I said during class, you could ask me if you had questions." All the teachers were very good, as I recall. Ms. Jin, in particular, knew I wasn't good at studying. She tried her best to help me and taught me patiently many times until I could remember what we learned. Ms. Du from the Office of Educational 
Administration taught us to beat the drums when raising the flag. Ms. Shi would come to the gymnastics room to ask me how everything was going and teach me the moves that I didn't know. Some classmates might hunch over the desk when writing. Then the teachers would ask us to sit up straight or pat us as a reminder.

The happiest time of day was during the lunch break. All the classmates enjoyed playing poker together. We got along well with each other. But sometimes, I would envy those who performed better than me. There were a lot in my class. While in the vocational department, our class had about 12-15 students with more girls than boys, gathering almost all students with strong hands-on abilities. Especially in terms of making steamed buns, the patterns made by some girls were much better than mine. This made me frustrated. Our pastry teacher Ms. Liu, who was also our deputy teacher in charge, would often encourage me.

\section{A Seven-Year-Old Tomboy Practices Gymnastics}

\section{Q: When did you start practicing gymnastics?}

Xing: Since I was seven or eight. At that time, I looked like a boy. Ms. Shi guessed I might be flexible since I was young, so she asked me to have a try in the gymnastics room. I didn't even know what she was going to do. Her original intention was simply to strengthen our body, without thinking about any competitions. In the old gymnastics room, she would directly step on your feet and try to hang you on the bars. Gradually, she gathered more and more students, while thinking carefully about how to teach the moves. But I didn't exercise much back at home.

Teacher: Ms. Shi believed that learning gymnastics might help to improve various abilities of these kids, so she established the first gymnastics team of our school. Le Xing was one of the members. The training was boring, but Le Xing never complained about it. Every morning, she came early to start training with Ms. Shi and stretch her muscles. She persisted in doing so through the years.

Xing: Ms. Shi thought the students she selected were satisfactory. Then the training officially started. Every morning, we came to the gymnastics room around 7 o'clock and practiced for 40-50 min, before we returned to the classroom and then did radio calisthenics. Under the guidance of Ms. Shi, we started from basic training, like stretching our legs, with figure and flexibility training, then it became increasingly difficult. Sometimes we might watch the videos on a computer to learn the moves. After I began these exercises, I also started to participate in various competitions. Without gymnastics, I wouldn't have those future achievements.

Back in 2007, I practiced artistic gymnastics, like uneven bars. It was difficult. Also due to the exercises, I got more muscles in my legs and bottom. Whatever trousers I wear, my legs don't look slim at all. But now there's nothing I can do. It's impossible to make my legs thinner again.

In the beginning, I didn't know how to do a cartwheel and couldn't perform it along a straight line. So, the teacher taught me to do it like this (demonstrating), just 
like a boy. She would support my feet and help me to turn over. I gradually learnt it this way.

The same went for the backbend. I started from initial exercises, in which the teacher supported me up and pushed me down. It was hard as well. Sometimes, I felt under pressure if I couldn't do it well. I would say to Ms. Shi that, "I feel exhausted. Can I call it a day?" Ms. Shi replied, "All right then. You can stop for now and think it over when you go back home." I would just do what she said.

I once slacked off, thinking about giving up. Originally, gymnastics sounded easy to me. I thought I just needed to do some sit-ups, listen to the music, and watch some videos of basic rhythmic gymnastics, and so on. To my surprise, it could be so hard that I yelled like a pig about to be killed when stretching my legs. The teachers would ask me if I still wanted to continue. Some other classmates also encouraged me, saying, "Lele, ${ }^{4}$ let's exercise together, just for fun." Then I was convinced.

At that time, Ms. Shi was younger and stronger. I asked her to be gentle with me, but she said she already was. To me, however, it was still too much. She pressed me so hard and so quickly that my head touched my foot in an instant. Now, I can't stretch my body like that anymore.

Later, I imitated Ms. Shi to stretch other students who were not that flexible. As I got tons of strength just like a boy, all the kids cried, "Ouch! Don't be so harsh on us, Lele." If I beat someone, it also hurt a lot. Apart from one student with Down syndrome, I always invited all the other team members like me to stretch. They tended to avoid me, "Oh no, it hurts so much." I would tell them Ms. Shi asked me to do this, and stretch them one by one. It felt so good. At that time, there were many students practicing together in a lively atmosphere. We didn't feel it was too hard.

One girl in the team had the same experience as me. Her foster family already had elder brothers and sisters. Later when her foster parents decided not to keep her, she was sent back to the welfare center, after which she didn't come to the school often. But now she leads a good life, living in a house provided by the welfare center.

Another girl in the team was also sent back to the welfare center by her foster family before the age of 18 . Now, she lives independently, though. She was one grade higher than me and came to our boarding school, the Pudong Special Education School, as late as the seventh or eighth grade. She studied well, with no serious issues concerning her IQ. It was just that she didn't like talking. In the ninth grade, her foster parents disliked her and sent her back to the welfare center. She never returned to school, nor did she go to the vocational department. Actually, returning to the welfare center is also good, enabling her to help kids younger than her.

Q: Apart from competitions, did you take part in any other activities during your school days?

Xing: I also learned dancing. It was quite simple. The school has always been organizing the dancing class, so I started to learn the basics, together with my training of gymnastics. Many kinds of dancing, including the traditional Chinese fan dance,

${ }^{4}$ Lele: nickname of Le Xing. 
and street dance, were taught step by step by our teachers acting as the choreographers. We would then participate in the shows held inside or outside the school. Sometimes we might come back later than 10 p.m.

I also took part in inclusion activities, in which we students acted as the inclusion journalists to carry out interviews, or attended knowledge sessions of Special Olympics. Our teacher Ms. Cai regularly took us to other cities like Beijing and Harbin, where we interviewed other athletes to know more about their hard training. We would get so nervous when we did the interviews.

The inclusion activities broadened my horizons. I met and wrote a letter to the mayor of Shanghai, and also put on a performance in the Century Park together with the famous dancer, Mr. Doudou Huang. I've kept many certificates and photos.

Gradually, I got to know more about Special Olympics. Once, I was selected, together with some other students and led by our teacher, to be in a press conference on behalf of our school. It was there that I met Tim. As I recall, he seemed to be some VIP like the chairman of the Special Olympics Committee. I was still a tomboy when we first met. We didn't get too familiar with each other, but as an enthusiastic American, he gave me a hug.

\section{Unforgettable Intensive Training in Tianjin}

Xing: I heard about Special Olympics from our teachers. Though I didn't know what it was like, I just wanted to have a try.

I took part in Special Olympics twice. The first one was the 2007 Special Olympics World Summer Games in Shanghai when I was in the ninth grade. Before the games, we had a 3-month intensive training in Tianjin as members of the national team. Previously at school, Ms. Shi was unable to provide the same training as the national team. So, in 2007, she and Ms. Wang applied for training in Tianjin, where they had well-equipped training rooms and professional teachers.

We then had new coaches for both rhythmic and artistic gymnastics. The 3 months were really tough. Every day, we got up at about seven, practiced for a while, had our lunch, a break, and then repeated the whole set of moves. We normally started from the basic fundamentals and exercises, then we did the moves. Oh my! We really had a difficult time on the bars. It really hurt a lot. Some tough boys did the pull-ups with their hands, until the skin, and even the flesh, was torn. Their wounds healed gradually. My situation was a little bit better. I simply hung on the bar, which got me some calluses. Now they've gone away eventually.

One coach was responsible for controlling my weight, since gaining made it harder for me to do the moves. To prevent me from eating too much or eating secretly at night, she would ask me to sleep in her room. She also supervised me during the breakfast buffet to see what I had for breakfast. I always felt so hungry.

Q: How was your relationship with the teammates?

Xing: We got along well. We all came from the same school and helped each other. During our days in Tianjin, the birthdays of several teammates, including mine, were 
in the same period. So, we celebrated together and had cakes. It was a lot of fun. Really unforgettable.

In 2007, there were two different gymnastics events in Special Olympics. Our team was also divided accordingly: some practiced rhythmic gymnastics; some others artistic gymnastics. My roommate Ms. Yang and I were in the latter. We still received training in the basics and flexibility together, but since I was in Level 2, a bit more difficult than her Level 1, we couldn't communicate that much or that deeply. In the final game, she didn't perform that well, with only one gold medal and some other silver and bronze ones. I won three golds and two silvers.

Q: Did you take care of yourself in Tianjin?

Xing: This was the first time that I travelled far away from home for quite a long time. Fortunately, we were independent enough, and we had washing machines where we lived.

Ms. Shi was with us throughout the training. She didn't even take care of her two kids, but treated us like her own children. Occasionally, Ms. Huang and Ms. Jin would also come to take care of us in turn, so that Ms. Shi wouldn't get overwhelmed. Besides, as we grew older, we were all obedient. We wouldn't wander around and make our teachers worry.

Of course, we had relaxing times as well. Otherwise, we would be worn out by the strenuous training every day. One day, the coach allowed for a day of rest, so we didn't need to go the gymnastics room. But Ms. Shi would still ask us to keep training in the hotel corridor with close supervision. She said, "You need to stick to it. Either flip, or handstand, just keep practicing your daily moves. Go, go." She was hoping that we could win gold medals for the honor of our school.

Normally we could rest on the weekends. But when we devoted ourselves into training, we never knew when it was Saturday or Sunday. So, the coach would grant us some holidays depending on the training progress. During the holidays, we either enjoyed talking, making some jokes or playing cards, going shopping or hanging out with our coach. Our coach was a local there. Our venue was close to her home, but we couldn't go visit. She had a harmonious family.

In 2007, she also came to Shanghai to be with us during the games. We once had her QQ number, but her husband didn't approve of our contact with her, and refused to give us her new number. This is how our contact ended.

We had so much fun during our 3 months in Tianjin. We had strict training, we were sore, we were tired, but a hot shower could relieve us; the constant encouragement of Ms. Shi kept us going. Actually, Ms. Shi got up even earlier. She trained with us, ate with us, with no rest and no complaints. She made a bigger effort than we did.

\section{Eight Gold Medals in Two Special Olympics}

Q: Tell me more about your first participation in Special Olympics.

Xing: I took part in it for the first time in the summer of 2007 in Shanghai. We lived in a hotel during the event. Since I was strong as a boy, I competed in the artistic 
gymnastics together with another girl. The rest of the girls normally took part in the rhythmic gymnastics event. We represented the Chinese team and I won three gold medals and two silvers.

I was so nervous at that time. After coming back from Tianjin, I even visited the competition venue in advance. I could perform well during my daily training; I didn't get stressed even during the opening ceremony, but in the final game, I got panicked. I've never seen such a big audience in the bleachers, or so much staff around me on the site. As a result, I made some mistakes in the vault and on balance beam. The moves were still finished though. In other events, like the floor and parallel bars, my performance was satisfactory. I had been confident that I was going to win five gold medals, but things don't always go as planned. Nonetheless, I thought generally, all our effort and the devotion of Ms. Shi during the training paid off. We strived to get more gold medals for the glory of our teachers and China. We must show our best, you know? There were some other team members who won five, or even seven gold medals (laughing heartily) (see Fig. 1).

Q: Did you participate in the next Special Olympics after 2007?

Fig. 1 Le Xing during competition

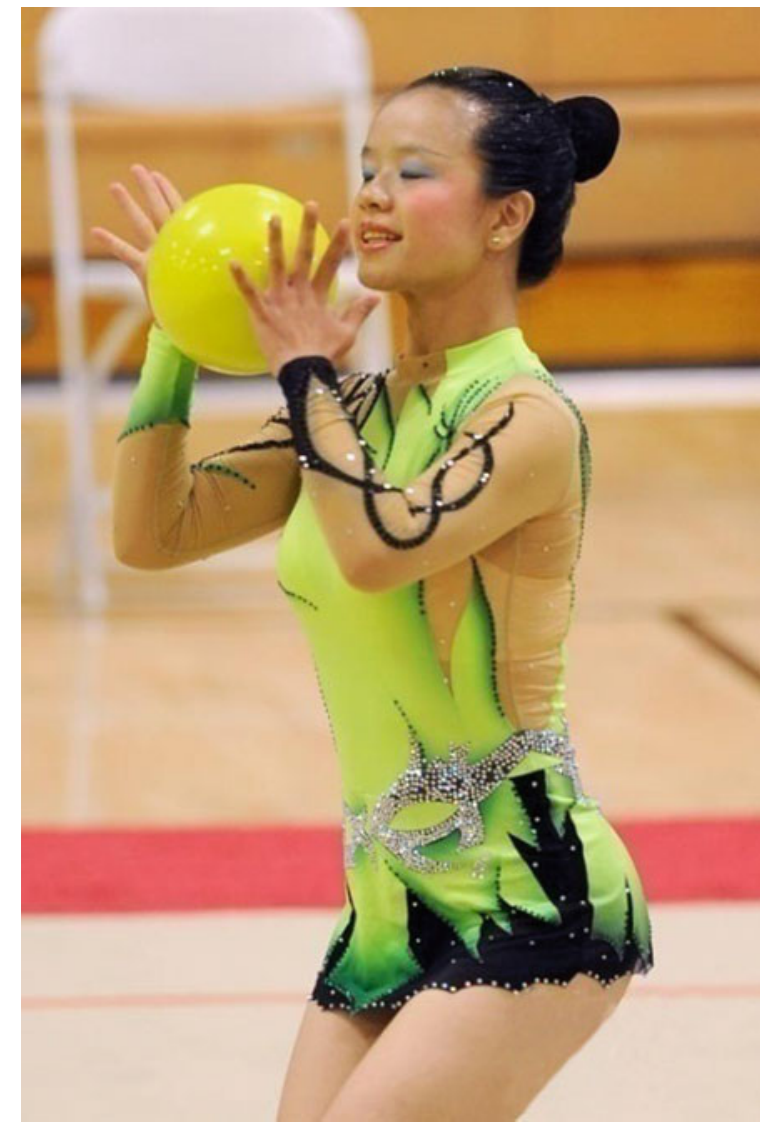


Xing: In 2007, I was already in the ninth grade. After the games, I graduated, and went on to study in the vocational department for 3 years. By 2011, when the European Special Olympics was held, I'd already become an employee and I was dating someone. As I worked in a shopping mall, it was inconvenient for me to ask for leave for training. So, I didn't go to Europe. There were several younger students who participated in it.

Later in 2015, I went to Special Olympics again. After I got married in 2013, gave birth to my baby in 2014, I rested at home for several months. When my baby was weaned around the age of 5 or 6 months, I was able to find time for training at school every morning. Then I started the intensive training in May and June, and went to the USA before the games in July and August. My mother-in-law was really supportive. I told her that, "I've never been abroad. Now the teacher invited me to a competition in the US, I want to visit this country." She said, "Of course, as long as you want to." She really supported me!

Then, Ms. Shi, together with eight of us, flew for $12 \mathrm{~h}$ to the US. We stayed in college dorms in Los Angles for more than half a month. We won five gold medals, which was quite good.

I was the only team member who was married. But the other members were basically the same age as me, only a few months younger. The two training regimes in 2007 and 2015, however, were somewhat different. In 2007, it was unforgettable as many classmates were all together. I felt like the days were extended. While in 2015, though we lived in the same school in nearby dorms, we didn't get that close as adults. The relationship was just so-so. Time flew.

Teacher: She just gave birth to her baby at that time. We asked her if she'd enjoy participating in Special Olympics again, and she accepted our invitation happily. Our training started in May and June, until we headed to the US. She behaved in a totally different way than last time. She was more mature with her own opinion. She also had the awareness to take care of younger members during our training. It was really considerate of her.

Q: How did you feel going to the US?

Xing: Passport procedures were kind of complicated. Someone took us to the passport agency in the school's cars.

I felt much more at ease this time. I've never been abroad, so I wanted to have a look at the strict training of foreign athletes.

The Americans were careful in examining our stuff. They also showed great hospitality, giving us many gifts in the dorms. Two people lived in one dorm with bunk beds. I was with Ms. Shi. We would set a time, like we got up after seven, then volunteers would take all of us, including other foreign athletes, to the school canteen for breakfast. After that, we would go to our venues for competition. It was far away. So, a few days later, we moved to our competition venues, also on campus. Therefore, we lived in two campuses in total, one was for relaxing before the competition, the other one was the competition venue. There were people taking us to the venue every day. When we knew our way better, we went to have meals by ourselves.

Foreigners were really friendly. They tended to say hi and smiled to everyone they met, whether they knew the person or not. Chinese people, however, might be shy in 
front of strangers. I couldn't speak English, so I didn't make any foreign friends, but we got to know some volunteers. They were Chinese students overseas who could interpret for us or taught us what to do. We all felt they were really nice. Before the competition, volunteers also took us for a visit on a ship. Sometimes, volunteers might tell us to take care if they didn't have enough time to show us around. Due to the language barrier, we either wandered around, or followed the mother of a student who could interpret as well. We might have a walk after lunch. Later, I discovered that there was Wi-Fi in the university, which enabled me to enjoy a video chat with my husband.

This time, I competed in rhythmic gymnastics. This was because I was a bit older, and all the other students practiced the rhythmic one, doing so could save some energy for Ms. Shi. During practice, I didn't get used to the soft and beautiful moves, as I was normally more boyish. Besides, I was kind of impatient, always making mistakes by not following the tempo. Ms. Shi provided guidance to me every time, and took us to other schools for training with professional coaches.

We competed in different levels and age groups. I was lucky to be in a group with the athletes of almost the same age. Just average players. I thought my performance was okay. But when I observed others, I felt like maybe I made mistakes, so I thought my score was low. In the end, when the score was announced, and we lined up accordingly, I actually did a good job. I got five gold medals; they were quite heavy.

The national team won many gold medals this time. Huai Wang, a male artistic gymnast, won seven medals. Among the girls, I won the most gold medals. Others got four golds and one silver, or one gold plus several silver or bronze medals (see Fig. 2).

We enjoyed a smooth flight back. All of us took care of each other. Since it took a long time, we sometimes got up from our seats to walk around when we felt uncomfortable. It was better when we finally landed.

After this Special Olympics, I also hosted the Special Olympics Unity Fundraising Gala Dinner in a hotel in Pudong District. It was held by Special Olympics East Asia, inviting Mr. Shiyi Pan, Ms. Lan Yang, Mr. Ming Yao, and some other celebrities and the Special Olympics ambassadors. I went there with my teacher, who wanted me to have a try as the hostess. Then the staff from the Disabled Persons' Federation also agreed with the proposal.

I think basically, I look the same as other ordinary people, but there might still exist some gap in terms of intelligence (pointing to her head). I was bad at Chinese and math, and I felt a bit nervous being a hostess for the first time, especially after seeing so many people. But it was okay. I wasn't alone. I was given a speech as the hostess before the event to practice reading it. There were also people guiding me if I encountered issues. On that day, I wore a qipao evening dress. I was with two other professional hosts: one man was the host of Entertainment Online, the other girl was a translator on an English channel. It was lucky that I performed well, with no big issues. At that time, I was already a mother (laughing).

Q: Does Le Xing still practice gymnastics?

Teacher: She was really good at somersaults, and loved the backbend a lot, right? 


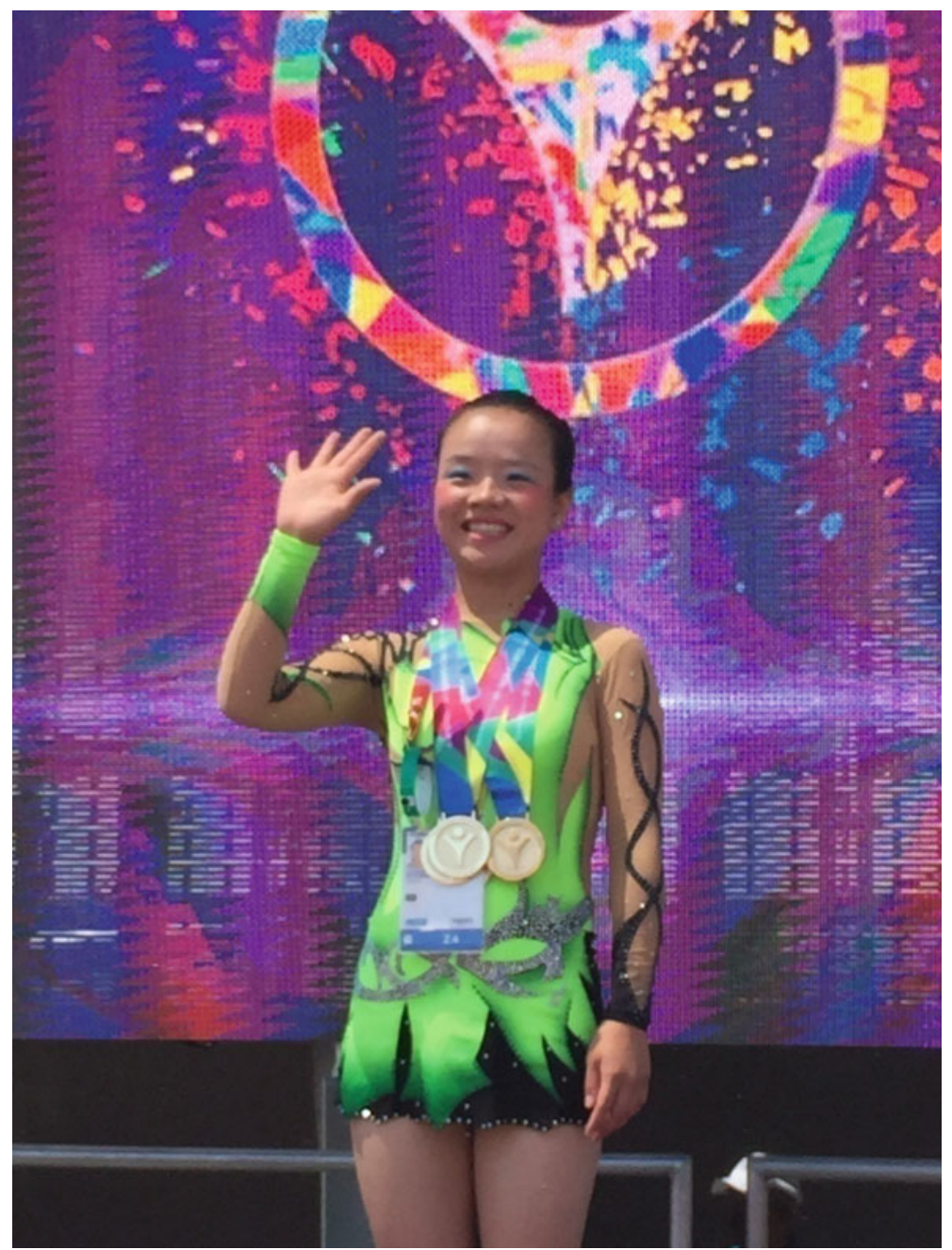

Fig. 2 Le Xing on the podium

Xing: I stopped practicing after the 2015 Special Olympics. I've been staying at home for a long time. Also, my health and my age don't allow me to participate anymore.

Ms. Shi has been the coach of our gymnastics team so far. She was younger and stronger when she taught us, so she was able to stretch us hard. Now as she grows older, while we become taller and heavier, she can't do that anymore. It also becomes harder for her to coach young students. Several days ago, I sent some costumes to Ms. Shi at school. She asked me if I still practiced at home, and if I could do the basics, like stretching my legs. I replied that basically, I didn't practice, but I might perform okay with the basics. Certainly, it can be hard when stretching your legs all 
of a sudden. You'll feel sore after a week and you just can't go back to the old days, as your muscles won't be that flexible. Ms. Shi also said our backbend was not as good as before.

Q: What's the impact of Special Olympics on you?

Xing: I was able to keep a good figure during the whole process from initial exercises to the final games. I didn't even gain weight after giving birth. I still eat, but not that much. I have the same figure as when I was a young girl; none of my colleagues believed I was already a wife and a mother. Gymnastics makes me well-proportioned and energetic.

My confidence was also boosted. Though I may not be the best member of staff, I'm still a good athlete. I can still remember the moves, and pick up all that we practiced within a short period.

\section{Began to Work After Graduation}

\section{Q: When did you start to work?}

Xing: June 2010. That was my last year at the vocational department. I worked as an intern for a while, and then went back to school for a bit. It was an unpaid internship at House. As they considered my performance to be good, and I also passed the interview, I became a member of staff there. They knew I had the disability certificate.

Starbucks normally recruits two or three students every year in our school. Some other students work as housekeepers at the Novotel Shanghai Atlantis. At that time, I tried to adapt to the working environment outside the school and the job was basically okay, so I just stayed as staff.

It was the first time that XX House recruited people like us. I was the only one picked. Normally more classmates worked at Starbucks.

$\mathrm{Q}$ : What did you do at that time?

Xing: I worked at the XX House at the Thumb Plaza on Fangdian Road.

Though I learnt pastry, it didn't mean that I would work in the same area. I wanted to have a try in a new field. Surprisingly, I passed the interview. Also, our teachers have informed the company of our situation.

When I started to work there, I thought it was a lovely and lively place with many customers. The salary, however, was low. During my first days there, senior staff asked me to get familiar with what we sold, and taught me how to scan the price tag.

There was an elder staff member who treated us well. I should have called her my master, but after we got closer, I just called her sister. She would teach me how to replenish the stock.

Teacher: In our school, we first recommend students to employers, and then assign jobs to the rest of the students. There were failed recommendations, while the case of Le Xing was successful. Her first job was at XX House, where she worked for about 2-3 years. Everyone loved her as she was nice and friendly. In the end, she resigned 
due to lack of salary increase, long commuting distance, late working hours, and a boring job.

Q: Could you please tell me more about your work?

Xing: The XX House operates from 10 a.m. to 10 p.m. The morning shift ends at 5 or 6 p.m.; noon shift is from 11 a.m. to 8 p.m. There was also an afternoon shift. Apart from printing the price tags, sometimes I also recommended goods to the customers, answering questions like, "Is it good?" "What's it made of?" We used to have meetings in the morning.

I went to work from Monday to Friday, and rested on Saturday and Sunday. The welfare was the same for all: no canteen, no accommodation, and we needed to pay for five social insurances and the housing provident fund. All the other colleagues treated me like everyone else. When we got closer to each other, they all called me Lele. One salary scale applied to us all. Depending on the job grading, salary could vary, with that of department head or senior staff being higher than ours.

All the colleagues were nice. Knowing about my condition, none of them excluded me. But sometimes, I didn't believe in myself, thinking that I still couldn't master everything after working here for quite a long time. Colleagues comforted me, telling me it was nothing. Just be honest with what you've done. They didn't take it seriously, either. The relationship among us was okay. Sometimes, I hope that they can consider me as an adult, instead of caring about me too much. I'm already a grown-up. I should be sensible and independent.

I quit after I got married and pregnant. It was already quite a long period.

\section{Farewell to the Foster Mother and Gaining Independence Due to a Relationship}

Q: When did you move out from the home of your foster mother?

Xing: 2013. When we become adults, if we can pass an IQ test organized by the welfare center, a house will be assigned. Therefore, at that time, I would go to the faraway children's welfare center on Zhongchun Road in Minhang District for review class every day. I went there in a shuttle bus at similar hours like those going to work. The welfare center also helped us with the review, for fear that we would fail. My mother said I would fail for sure, but had no comment seeing that I passed.

I didn't tell her about the house. She didn't care about the location or the further arrangements either. When I got the house in Hongkou District, my teacher took me there, as she didn't even know about it. She kicked me out later because she thought I lied.

My mother tended to check my phone. Whenever my Nokia rang, she would check it first, whether there were text messages or not. In response, I had to delete all the messages. But when I had a boyfriend, I had to read his messages. Gradually, I was caught by my mom. I had to tell her I had a boyfriend; the teacher was the matchmaker. She was upset as she thought I was still too young, while actually it was 
already the right age. Living here, I wasn't allowed to hang out with my boyfriend. So, all I thought about was moving out, so that I could get rid of her control, enjoying my relationship, going wherever we wanted, and going shopping after work.

Gradually, I got so angry with my mother as she kept interfering with my relationship. That's why I told her about the IQ test and house. I said I could move to that house. She replied, "What would you do there? You have nothing there, how could you live?" But I'd made up my mind to move out for my freedom of relationship. She even told my brother about this, and my brother just said, "Go ahead, and never come back."

Then, I moved to my new house in Hongkou District, Puxi. My in-laws were so kind as to take some daily necessities to the empty house. But a bad thing was the house was quite far away from my workplace. If I finished at 9 p.m., it was inconvenient to go home. To solve this issue, I still lived at my mother's home for a while and took some personal stuff with me. Once, I wanted to live at her home again, so I asked if I could go back to have a shower and stay for a night. She agreed. But when I came back, she treated me like a stranger. She opened the door for me and gave me things needed in the shower, but I couldn't find my previous slippers. I had to walk in the bathroom barefoot. After the shower, she took away my keys to the house, and kicked me out. "You can go now. Don't sleep at my house," she said. I thought, well, whatever. I had my phone anyway. It was a weekend. When I walked out of the gate, I saw my brother playing basketball. He loved hanging out with his classmates, while I always stayed at home. At that moment, I didn't want to talk to him. So, I called my boyfriend and told him to pick me up as I was kicked out by my mother. This was how I moved into their house.

After taking away my keys, my mother threw out everything I've used, like bowls and mats, into the trashcan. She just couldn't stand the sight of things used by others at home. Therefore, I had to take away all the rest of my things. I couldn't go back any longer, nor did I want to talk with her. Shortly afterwards, she gave me my payroll card. There was not much left.

Q: Who spent your salary?

Xing: Previously, I respected her. I said, "Mom, just take my money. How about buying a TV?" If she spent it, it was understandable. After all, she raised me.

Q: Did your mother and brother ever visit your new house?

Xing: They didn't know, nor did they ask. They only knew I was in Puxi. It was quite far away. I couldn't tell the direction, so I really had a hard time taking the subway.

Q: You lost contact with your mother since then?

Xing: I was in the relationship for a long time. By 2013, when we got married and held our wedding, my mother-in-law told me to invite my foster mother to the ceremony. So, my husband and I visited my mother with some gifts, wedding candies, and the invitation.

She acted weird on that day. She opened the door for me, and gave me a pair of slippers of unsuitable size. I told her, "Mom, this is my husband. We're about to get married. This is our wedding invitation with the date and place. We hope you can come." To my surprise, she refused to accept anything. But we just put all the things 
on the table, as what my mother-in-law had told us before we set out. My mother could do whatever she wanted with them. She also talked in a weird manner. During the visit, she suddenly said politely that, "Go get some water for your husband." I did it as I haven't been home for nearly a year. In the end, she didn't come to my wedding.

My brother was out with his girlfriend on that day. But my mother must have told him about my visit and he could see my invitation. Anyway, he didn't show up at my wedding ceremony, either. Similarly, he didn't invite me to his wedding as well. I wasn't even informed. Once, I encountered a friend of my brother in the hospital when my son was ill. I was told that my brother got married at the end of 2014 and lived well.

I know little about their current lives now. Sometimes, I suggest to my husband that maybe we could drive around in the Hai X New Village. We've not been there for long. It has undergone great changes. Though I can still recognize my old home, I feel somewhat distant from it and reluctant to approach.

Q: Do you still call your foster parents?

Xing: Currently no. I don't call home anymore. It's pointless. We ended the relationship with them when they didn't show up at my wedding. Once, I met one of the buddies of my brother. The man told me my brother got married, new house decorated, and his mother was also well. So, I guess their situation is good. I didn't save, nor could I remember my brother's number, but he had my number actually. I haven't changed it. As he doesn't call me at all, I decide not to contact them.

Q: Could you tell me more about the houses distributed by the welfare center?

Teacher: The policy is like this: as the government funded the welfare center to raise the children, it will make an appraisal of the children's ability. If there's no problem, then the government will arrange accommodation and a job, indicating that the child becomes an independent adult; if not, the child may spend the rest of his or her life in the Chongming No. 2 People's Hospital. Everyone only has one chance, so it's quite critical. For those who perform well in the appraisal, they will be allocated to different districts based on the quota, just like the lucky wheel. We can't predict their final destinations. In the case of Le Xing, she was assigned to the Hongkou District, whose people's government was responsible for her housing and household registration as her job had been settled by our school. This way, her collective registered household was transferred to that district. The house was shabby in a poor condition, simply a shelter. She was just a girl who had never lived alone before. How could we feel at ease?

Xing: I was the only one in the Hongkou District. Another classmate was allocated to another different subdistrict. One of my friends was lucky. She got assigned to a subdistrict of the Yangpu District, receiving good care from the government. First, she was arranged to live in a hotel. Then the government provided free decoration of her house. It was a single room apartment with two floors. She was also provided a job as a registration staff in the library. She only needed to record information on borrowed and returned books. It was an easy job.

I don't live in the house now. The condition and environment were unsatisfactory. At that time, I got along well with staff on the residents' committee. I was allowed 
in the house after informing the landlady. Later, as I didn't live there very often, she took the house back to avoid a waste of resources.

I didn't own the house. The government paid the rent, so that I had a place to rest after work. It was an old-style public house. I paid for the living expenses, including food. I was in the relationship back then. My future mother-in-law and other relatives took good care of me. They would bring many things from their home to my new house, traveling a long distance. We went there in two cars, one of which belonged to the brother of my mother-in-law. Actually, since I went to work in Pudong, sometimes I might return home at 10 p.m. after getting off at 9 p.m. It was quite inconvenient. That was why I seldom lived in the new house. I think I've lived there for less than half a year.

After I was kicked out by my mother, I just moved to my husband's house and registered my household here. The assigned house in Hongkou was taken back, as I said. The landlady decorated it and rented it to others. My things were all gone. Later, my mother-in-law tried to ask if it was possible to get the house back. The reply was that I was married; my husband had a house, and if that the area of this house was above a certain standard, then I couldn't get my Hongkou house...

Teacher: Actually, the government of the Hongkou District was trying to shirk its responsibility. I once told Le Xing that you were lucky as your husband and mother-in-law treated you well. Otherwise, you would have had nowhere to go.

Xing: Yeah, my mother-in-law was far-sighted. She once talked with the staff in the subdistrict of Hongkou, asking them what if I was excluded by the husband's family. She also asked if it would be possible to assign the house in Pudong; even a small one would do. This way, I still had somewhere to go if anything happened. But there was no reply from the government... So, I didn't get anything in the end. Currently, I mainly rely on my work. My household is registered together with my husband, mother-in-law, and my son. My father-in-law is registered in a separate household.

Teacher: Their house is okay (laughing). Fortunately, there's still a house, right? Otherwise... You need to cherish your life and be optimistic. Your life now is quite good, actually. There was a time when you were quite negative. But from a different perspective, you're better off compared with Ms. Zhang and Ms. Chen. Don't always focus on those who are more successful, okay? Think about what you have: a caring mother-in-law, a supportive husband, a lovely son, a good job. You even have more houses than me (laughing). Though I'm the headmaster, I bear much more pressure, right? So, just be content, happy, and grateful. Your life improved a lot. You don't come to complain, but ask me about my health. It makes me happy, as you know how to take care of me.

\section{A Teacher as a Matchmaker}

Q: How did you meet your boyfriend? 
Xing: Ms. Ying Wang introduced him to me. He was also a student in our school (see Fig. 3).

Teacher: Her background was special as she came from the welfare center. At that time, she was suddenly allocated to a house far away on Liangcheng Road of the Hongkou District, and she had to live on her own. It was really... For us as her teachers, who treated her as our own kid, we worried about her a lot. During her school days, we've always told her that when you grow up, be careful in picking your man. This wasn't about being picky, but pragmatic. I told her do keep her eyes wide open.

I've known Mrs. Sun, her mother-in-law, for a long time. She was a driver in our school. In my opinion, this family was quite reliable and honest. Mrs. Sun was also a very nice and genuine Shanghainese. Her son is the husband of Le Xing, a quite handsome boy. He's the only son of the family. His parents are just common

Fig. 3 Le Xing (left) and her teacher, Ms. Ying Wang

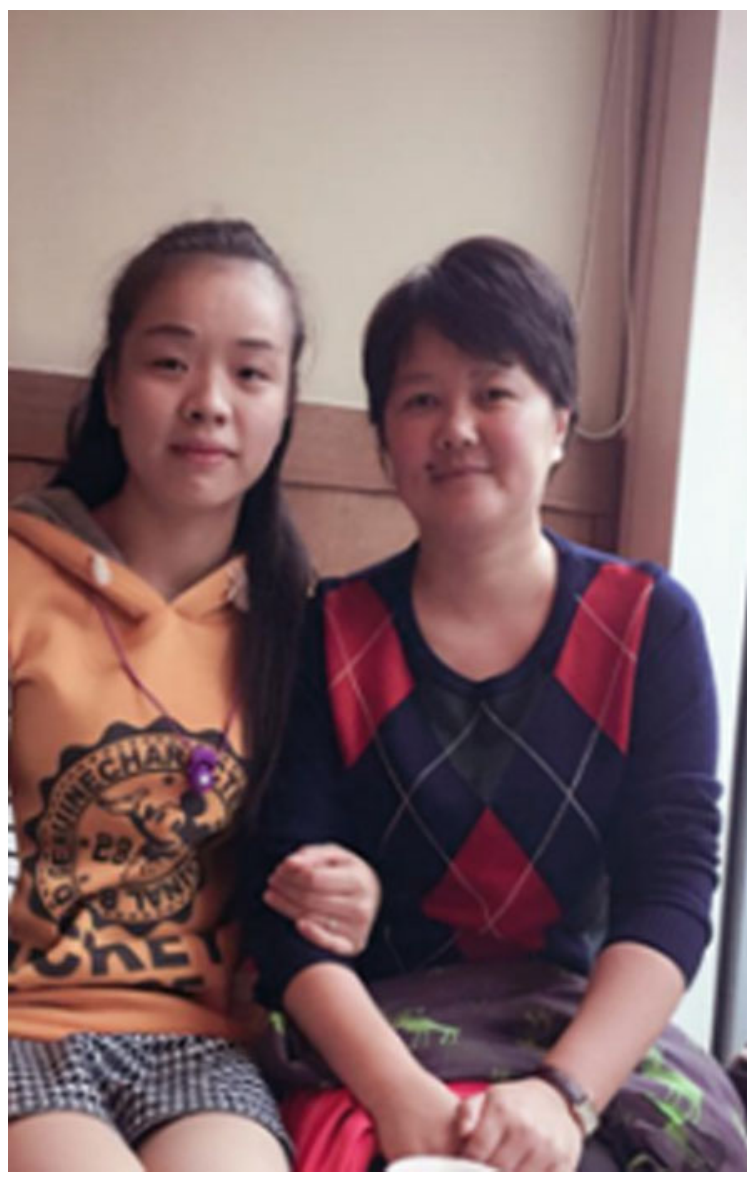


people. The father isn't very talkative, while the mother, Mrs. Sun, is very capable. She considers Le Xing as her own daughter.

I thought that the boy and Le Xing shared some similarities. He also graduated from our school, two grades higher than Le Xing. They communicated well. Besides, the boy's family was living in harmony with good living conditions. I considered this was a good choice for Le Xing, as she could rely on the family in the future. I was really being practical.

After all these considerations, I asked Le Xing, "I've found a boy for you. Would you like to meet him?" She replied yes, shyly. So, I arranged their first date in a KFC. Surprisingly, the two schoolmates liked each other at first sight. Chen Zhu loved Le Xing a lot, right? They complemented each other, one was more open, while the other was more of an introvert. From then on, they started their relationship and got married smoothly. I was really happy. I guess they have some shared topics and similar interests. Chen Zhu also got his job through our recommendation. Sometimes they went to watch movies together... (laughing).

I once said to her mother-in-law that, "As you know about Le Xing's situation, I trust in you, believing that you can take care of her as your own child." She said no problem. Then I went on to say that, "You can also teach Le Xing about life. After all, she's still young. You can turn to me for help when she encounters difficulties or doesn't behave. She still follows my advice." Therefore, Le Xing would sometimes send me some messages through WeChat about complicated issues that she couldn't handle. I would talk with her and provide suggestions. One can never grow up without any obstacles; the key is how we cope with them and get through. Be nice and kind to others, and God would protect us. This is my motto, and I've always shared it with her. In critical moments of life, like your marriage and birth of the baby, I believe the motto always applies, right? Other teachers, like Ms. Liu, cared about her a lot. We were so happy to learn about her wedding, to see her in the beautiful wedding dress, and to share her wedding candies. We were so touched when we saw her in the dress, feeling like our own child was getting married. From then on, she has her own home and someone to rely on. We were all witnesses to her growth. She always had our best wishes.

Xing: My husband is the only son of his family. I was born in 1991, and he is 3 years older than me. My father-in-law only stammers a little bit, while my motherin-law totally outperforms in terms of both IQ and EQ. She's also quite talkative, while my husband and I are just not comparable. So, I'm normally straightforward in expressing my thoughts. She herself knows she's better than us in these aspects as well. My husband is quite quiet. I'm much more direct; I talked a lot when we first met each other (laughing).

We enjoy our relationship a lot. We both worked when we started it. He helped in the kitchen in a holiday hotel in Pudong. I was at the XX House and got off late. Based on my shift, I was normally off duty during weekdays, while working on the weekends. So, we would go to watch a move after work, or... (tittering).

After a year, we got our marriage certificates and held the wedding ceremony. We didn't choose a particular date for the wedding as local people, since we didn't think it mattered. We finally chose March, when my mother-in-law retired. We planned to 
have our baby 1 year after the wedding, so that my mother-in-law could help us take care of the baby at home. We didn't invite too many teachers to the wedding. We would have been embarrassed if they gave us gift-money. Of course, the wedding candies were shared with everyone.

I really enjoyed the relationship, but I had less freedom after we got married. We needed to work after all. Predicting all the work ahead, we travelled to Xiamen City for a week together with my sister-in-law before I got pregnant. She arranged all the schedules and booked the tickets. We paid her afterwards.

Now that I have a family, I need to learn how to save money for my son. I can't go to the cinema that often as before and enjoy moments only with my husband. I have to go home after work, devoting all my time to my kid. Normally, the whole family will take my son to play and have dinner together. I don't need to pay.

Teacher: Married life is indeed not that easy, but you're also quite happy, right? You can travel to Hong Kong and Beijing (laughing).

\section{Baby Son Brought Happiness}

Q: How long after you got married did you get pregnant?

Xing: During the pre-marital examination, neither of us had any problem, but we didn't plan to have a baby soon. I got pregnant in 2014, a year after our wedding. At that time, I still worked at XX House. Normally, my period was punctual, and I would record it on the calendar. But one month, it wasn't on time. I waited and waited, thinking it might be late. Then I asked my colleagues about this, they told me not to worry and wait for some time. Some of the married, experienced and elder colleagues suggested buying a pregnancy test kit, which didn't show the result. Therefore, I told my mother-in-law about this. She didn't ask me in detail, but took me to the Renji Hospital, a public hospital next to the Children's Hospital, for a pregnancy test. Then I knew I was pregnant.

My God, I felt so nervous when I learned the news. My colleagues told me to take care of myself at work, and avoid abrupt movements. I just thought all this came too soon. On second thought, though my in-laws didn't urge us, they still asked about it. As they were getting older, it might gradually become harder for them to help us taking care of a baby. After my delivery, I basically stayed at home, without going to work.

In the past, when my mother-in-law gave birth to my husband, pregnant women still needed to go to work. Perhaps due to lack of rest, she didn't notice the cord around her son's neck. This, plus the absence of the C-section option, and the large head of her son, made her delivery quite hard, and at last, her son was somewhat... The baby also stayed in the infant incubator for more than a month after birth. Thinking about all these negative consequences, my mother-in-law asked me to rest at home. She was worried about me, and my baby, as I needed to stand for a long time and carry heavy things at work. My husband and I already faced some problems, what if there's something wrong with our baby... 
Q: Did you feel nervous during the pregnancy?

Xing: As my belly grew bigger and bigger, I was a bit... nervous, actually super nervous, especially shortly before the delivery. The doctors bluffed us at first, asking us to sign some consent letter indicating the possible risks and consequences. I also did a C-section eventually. The delivery room was really cold; I felt scared. Then I felt nothing during the delivery as I was given anesthesia. But after that, I couldn't eat for $6 \mathrm{~h}$. That was really painful. Then the next morning, I was asked to walk by myself. As the wound wasn't healed, it hurt a lot when I had to go to the bathroom. During that period, as my husband had to go to work, my in-laws took turns to attend me. It wasn't that convenient for my father-in-law to take care of me, like cleaning the body, and so on, so he took care of the baby occasionally. My mother-in-law made the most effort, staying in the hospital all day long.

She also took care of the baby when I breastfed. She slept with my baby son in another room and simply asked me to breastfeed when he cried. It was winter at that time... No, sorry, I gave birth in July, so it was in September. It was already getting cold. Taking my son to the bathroom in the middle of the night was really tough work.

Q: Did you run tests on your baby?

Xing: I did all the pre-natal exams, including the screening for Down syndrome, but no screening tests on him after he was born. During pregnancy, the doctors always suggested to have some check-ups in case of water on the brain, saying that my son's head was larger than normal babies. We were worried about this. So, we went to the Renji Hospital for a B-mode ultrasound, which wasn't clear. Then we went to another hospital in Puxi, did the ultrasound again to check my baby's head. This time, with advanced equipment, the image was clear. The doctor didn't mention anything wrong with the result, saying that we could wait after the birth of the baby to see if there was any problem. So, we felt somewhat better.

The doctor didn't point out anything wrong. I think my son should be... okay. He's a normal and smart kid. Now he's two and half years old, with quick responses.

It's just that people say his head is big, especially the back of the head. Also, he doesn't like talking. We've already signed up early childhood development courses in the afternoon for quite some time, hoping that he can become an independent ordinary kid. Now he can say "mom" and "dad." He knows the location of things at home. He also has his own idea of who he wants to sleep with, grandparents excluded.

Q: Does he look like you?

Xing: My son looks a lot like his father. I find almost nothing similar to me.

Q: How's your life been going after you became a mother?

Xing: My son is taken care of by my in-laws during the day, and me at night. He always takes his grandparents to the door and waits for me to come home from work. He also rummages in my bag to find out what's in it. On Saturday afternoon, I take him to the courses. Sundays are also devoted to him. The schedule is quite full. Sometimes I also complain, since he takes up all my time after work and always clings to me and my husband, especially when having meals. My son's closer to me. I also blame him sometimes. He'll cry, become naughty again, and behave himself if you just ignore him. 
Teacher: Now she talks about her son all day long, telling us that she'll work hard to buy milk powder for him and save a lot of money for his future.

Q: You and your husband have been getting along well. How's your family life?

Xing: It's okay. We love each other a lot, but there has been some tension after we got married and had a kid. I sometimes think he can't do housework very well. He's an introvert. When you see his face turning red, he is getting angry. But if you ask him to help with something, he won't speak. Like when I insist that he showers my son, he'll say he can't. He's afraid that he can't do it.

Most of the housework is done by my in-laws. They buy the food and cook for us. I also want to cook, but as is known by all the teachers, I'm not like a gentle girl, but a rash boy. I'm bad at this kind of work. When I was at the home of my foster mother, she always told me to think over what to do first and what to do next before actually acting. I wasn't able to straighten out. I normally did things as I saw them. Now that I've become a mother, I try to act in an orderly fashion. After getting up in the morning, I'll first dress my son, sit for a while, then his father gives him some water before going to work. Next, I'll help my son wash his face, brush his teeth, and have breakfast. This is our daily routine. My son is also picky. He decides who can dress him. He looks for me from when he wakes up in the morning, refusing his father even when he's crying, unless there's no one else to comfort him. In the evening, we also have fixed procedures. I need to take off his shoes and change his clothes after I arrive home.

In terms of education, the responsibility mainly falls upon my mother-in-law and me. My mother-in-law teaches him numbers. Every day, I say "two," and ask him, "How old are you?" He'll answer, "I'm two," while making the gesture of "two." He may extend only one finger sometimes, then I teach him to extend the second finger. Besides, I teach him to say "mom" and "dad," and so on, asking him, "What do you call me?" I ask him to say the words clearly. Sometimes I let him call his dad, but he won't. He learned to call me "mom," though. He also knows where things around the house are.

I also bought a small toy house to teach him to put toys away. In the meantime, I teach him about colors. For example, I may say, "Give me the red car, dear." He'll choose one, think it over, and give it to me if he thinks this is the right one. He knows all these.

It's just that he's similar to his father in terms of character. I'm quite talkative, but if I take my husband to the home of a colleague, for example, he won't talk with people he doesn't really know. My son is the same, only talking to people he knows. His grandfather is also an introvert and honest. Considering his age, he has less energy taking care of my son than the grandmother. Also, grandmother pays more attention to his nutrition and cooks well. She does more in this respect.

My son has his own preferences. If neither Mom nor Dad is at home, though Grandma is more capable, he still asks Grandpa to take him to play at the door or in the grocery market in our community. If everyone's at home, he only comes to me. Even when I ask him to say Grandma, he still says Mom, calling everyone Mom. In this case, I ask him, "How many moms do you have?" "Five." "Which five?" He shows me one hand, counting all the five fingers (laughing). 
If he doesn't sleep at noon, I'll take him in the cart and walk around in our community. Yesterday, I took him to Puxi in a bus and bought two pieces of clothes. His grandpa paid for it. My son knows how to play and everything, basically not different at all from normal kids. He simply talks less, and the back of his head looks bigger. That's no big deal. After all, we took him to have a brain test, where some hood covered you as you laid down, and the doctor didn't say anything. If there was really something wrong, the doctor would have said something...

My son also eats a lot, almost non-stop. For example, his grandma cooks porridge every noon and evening. He always finishes one full bowl, even more than we do. In addition, he loves noodles, including the wrappers of wontons, and vegetables, like potatoes, green cabbage, etc. He doesn't like meat, nor can he eat it, since his teeth aren't strong enough to chew, and he may swallow it directly. Now I still breastfeed him at night, but not during the day.

He's kind of independent. I train him to go to the bathroom during the day, so he doesn't even need to wear a diaper. I ask him, "Do you want to pee?" He'll reply yes. Sometimes, he doesn't know how to say "pee," then he covers the part with his hands, and may pee on himself if it's a bit late. He poos at night usually.

Q: Have you thought about making him a gymnast as well?

Xing: Currently no. It depends. I'll let him learn what he loves. My mother-inlaw hopes he can learn swimming to strengthen his body. She actually guides the whole family. She hopes my son can be a normal kid unlike me and my husband, and become independent when he grows up. Anyway, he has opportunities to learn. He can just learn what he's good at.

Q: So, currently you and your husband go to work, while your in-laws take care of the child at home after their retirement?

Xing: Yeah, it was like this before. We go to work and they stay at home with the baby. In our neighborhood, it's always the parents looking after their children, and mothers normally stay at home until the children go to school. So now I decide not to look for a job. There aren't any good jobs, either. We'll see.

Previously, I got a higher pre-tax monthly salary of 3,500 yuan, with 300 yuan of tax. My husband works at the DQ, earning about 2,900 yuan a month. He works for 5 days and rests for 2 days a week. The holidays aren't on Saturday and Sunday, but two separate days during the week. He mainly makes ice creams and cakes. They also offer takeaway now. They're quite busy.

My in-laws suggested "that now you're both adults and have become parents, you should save some money." Normally, I pay for large expenses, like half of the course fee; while my husband pays for smaller items, like milk powder. But still, as we don't earn much, my in-laws actually pay more with their retirement funds.

Q: Who's in charge of the money in the family?

Xing: I' $m$ in charge of us two. My husband decides how he spends the money, but he'll tell me if he receives the salary and how much after I ask him. Now I applied for a text message service, informing me of the salary either through email or short messages.

We may have difficulties in dealing with money, but we don't blow money anyway. We buy what we need. My in-laws tell us to save money for the kid's schooling. This 
is true. Since we didn't receive much education, we must send our son to early development courses, which cost more than 100 yuan each time, and to formal schools. We need to start planning now, and give him a chance to learn as long as he can keep up. There's a teacher in the early development class who gets along well with us. I mentioned to her that I wanted to send my son to the kindergarten next year to see if he could fit in after maybe 1 day, and asked her to help us decide if my son can make it.

We still have another house in the Changning District. After it's decorated, we can have an extra source of income from the rent. Since we didn't perform well at school, the education of my son must rely on teachers in the future. The son of my husband's sister is in the third grade now. He goes to extra classes every weekend. A lesson from 1 p.m. to 4 p.m. costs more than 100 yuan! That's really a lot! We've spent more than 30,000 yuan on early development. Starting from March next year, we'll send him to the kindergarten, where he'll stay all day. This costs 18,000 yuan, including meals.

Q: Have you thought about having another baby?

Xing: No. We're not that capable. This child already has a big head, what if the second has the same issue... My in-laws are also too tired to look after another baby. Most importantly, though we have enough houses, we don't earn enough money, and we don't know how to educate children well. Even the couple of doctors living upstairs only have one daughter.

The two doctors major in design, leading quite a busy life. They also get along well with us. Once, they said, "Lele, after the Spring Festival, we'll try to see if there're good jobs for you." I said okay. They're from Xi' an City. Normally they go back to their hometown during the Spring Festival. They say nowadays, companies either recruit people with a diploma, like an undergraduate, or a postgraduate, or with certificates provided after you pass some exams. But we only have our graduation certificates, which are useless. As such, it's nearly impossible for us to find a good job. My previous job was good actually. If there were no customers, I could sit and rest, and sometimes invoice people. It was relaxing. Unfortunately, I was fired.

Q: Apart from your family and teachers, do you still contact other relatives or friends?

Xing: No, I only have one BFF. Among the family, I'm close to a cousin, the daughter of my mother-in-law's eldest sister, and my nephew. They're really considerate. Sometimes during festivals, we go to the home of my grandma (mother of mother-in-law), where my brothers-in-law and sisters-in-law gather together. Our generation have grown up; all the others know about our situation.

I call Ms. Liu occasionally, as I know she seldom surfs the Internet. I would ask her how it is going and chat with her. Previously, my husband had a fight with my mother-in-law. This made me worry a lot...

Teacher: There was tension between her husband and her mother-in-law and she felt sad, lost, and worried. I think this is quite normal. She suddenly lost her sense of security, right? What if they quarrel?

In response, I taught her some strategies. I said, "You should continue to get along well with your mother-in-law. Just treat her as your mother. It's normal that a mother 
gets angry at her child. Now something happens, you and your husband should reflect on it together. This is not solely about your husband, but the two of you. You need to persuade him not to get angry, but to find out, together with him, what makes his mother unhappy. At least you know she means well, right? It's possible that you need to change how you speak and in what tone... You're a family, there's no good or bad, and right or wrong in terms of housework and daily affairs. As young people, I hope that you both can take into consideration the effort of your mother-in-law in taking care of your son and doing housework. You should tell your husband not to act like this. Both of you should respect her and be nice to her. Meanwhile, don't get involved in it. Everything will be fine after a few days." When I was free, I'd ask her how it was going, and she said all was fine. I think she's becoming more and more mature in dealing with complicated matters.

\section{Early Childhood Development Courses for the Son}

Q: When did you take your son to the early childhood development courses?

Xing: It was my mother-in-law's proposal, as she saw a kid in another community attend this kind of class. Therefore, we went to the Center in the Shanghai Expo Park, which is in a good condition and has acceptable service. We attach great importance to education, and we want to try, so that he won't repeat our own experience.

When he went there for the first time, he didn't talk to anyone. It was a new environment for him. According to our original plan, if he could speak, then we wouldn't send him to early development class. But in the end, we had to send him because he rarely talks, just like his father. At home, I was the talker, while my son seldom talks, unless you ask him what he wants to do.

If I don't go to work, I'll take him to the class. Each week, he has both interpersonal communication classes and music classes on Wednesday and Saturday. He loves the latter a lot. Actually, the content is basically the same each time. Teachers normally review what was learnt for two to three times, before moving on to new things. His father also takes him to class. If we're both available, he'll want to be with his father.

Currently he can catch up to the class. Sometimes, he gets lazy. In the first class, when the teacher asked him to introduce himself to everyone, he just wouldn't do it, however, you nagged him. When he grew up a little bit, I told him, "Go ahead," he could go to the podium on his own. The teacher would teach him how to say the sentences. All the classmates would applaud. After that, he would rush down to me. He actually felt excited, but he was timid as well. Gradually when he became more familiar with the environment, he could go up to speak, he knows where everything is, and how to go to the bathroom. He normally plays on the slide for a while before the class as a warm-up.

Among the class, my son is the only child who talks less. He may talk with some other children if they get along well. There's another kid several months older than him, who still uses a pacifier. We didn't use this since he was little, for fear that 
he would get used to it and wouldn't let go. This girl is also very close to my son (pointing at the photo).

One thing I don't like about him is that he's too clingy. Once I'm home, he's simply attached to me. I can't fiddle with my phone, but only play with him, or watch him play, at least. He may drag me to play with his toy cars. He knows that I don't want to teach him about what he learned in the class. Occasionally, he would say, "I want to have the music lesson." If you say, "Dong dongqiang" laugh.

Now he can only say words like "mom," "dad," and "hello." He talks more with us at home, but becomes timid when he's outside. Today, I took him to a park to play on the slide. He only dared to play if I went up the stairs with him. I couldn't just wait on the ground. Last time, all the parents also had a class called the psychological security service. I knew that my son was timid and lacked a sense of security. The teacher told me, you couldn't tell a kid that he couldn't make it, as it would take away his confidence. You needed to talk more with him, and guide and encourage him.

Though he still doesn't talk that much and is unwilling to say hello, he has already made a lot of progress after the training he had in class. The teachers also agree. In the interpersonal communication class, the teacher asked everyone to introduce themselves. Some kids were able to tell others how old they were and their names. Our son actually knew it, but he was just scared, seeing that many people. When he was on the stage, the teacher asked him, "How old are you?" and helped him say the answer, "I'm two." Then he'd love to follow. It depends on the situation and his mood. At the end of the 45-minute class, I told him, "Haohao, the class ended. Go say goodbye to your teachers and give them a hug." He would do it, so long as you made it clear to him. We also added the teachers as our WeChat friends. Sometimes, I threaten my son, saying that, "Be a good boy. If you don't want to sleep, I'll tell your teacher." Then he'll go to sleep. He's obedient to his teachers.

He also likes pretty girls. Currently, he gets along well with a little girl 7 or 8 months younger than him. She lives upstairs. He may share things with her. As I've mentioned, he's more active with someone he knows, but won't talk with strangers at all. He would hug me and cling to me, including during the early development class.

Raising children is not that complicated in an ordinary family, but we're different. When I take my son to the class, I can sense that we're slightly different from all the other normal parents and families. I hope that they won't find out, and I try to do my best within my abilities. Sometimes, I'll state clearly to the teacher about our real situation, and ask her to pay more attention to our kid and teach him with more patience. I have to do so, since it can be troublesome if we can't explain what my son wants to know at home.

Teacher: This family really tries hard to raise the child. You have some photos and videos, right?

\footnotetext{
${ }^{5}$ The sound of beating drum.
} 
Xing: Yes. This one is a swimming lesson in the early development course. In this picture, his father took him to the class, which was an introduction to Japan. My son carried an umbrella, pretending that they were in Japan. This picture is my son in a Japanese outfit. This one was taken when he played in the Expo Park. He loves playing with little toys and loves toy cars. This is him playing in a shopping mall. He actually has been to many places, but not abroad yet. These are him laughing, being lazy, being ill, drinking milk at home, and at the home of my husband's grandma...

This is the son of my BFF, who's also my classmate. He's younger than our son (pointing at the photo), and still crawls. So, I give my friend all the clothes outgrown by my son. That day, she came to meet me, and experienced the early development courses with me. She also wanted to send her son to it, but she couldn't afford it. She married a man from other places. No house, no strong financial background. They just bought an old-style house at a price of about 740,000 yuan and they needed to pay the mortgage. The house seems to be located in southern Shanghai. I once visited her house by taking the Hunan line, which took a long time. She's quite capable, as she works at Tesco now. But due to the long commute and low salary, she's always looking for a new job. Actually, changing jobs can be really difficult nowadays.

\section{Two Jobs I Found by Myself}

Q: Did you start working again after having your son?

Xing: I stayed at home for a while after participating in Special Olympics for the second time. I weaned my son off when he was 8 months old, then I tried to find some job in the catering industry and learn something. At that time, I was on good terms with our department head in the XX House. She knew about my situation, and treated me like her little sister, just treating me as a normal person.

I knew the Teahouse, but I didn't know she worked there. I went to visit her workplace, thinking it looked good, and the overalls were also beautiful. She introduced to me the job, and asked, "It's really hard. How can you bear it?"

My mother-in-law also went to the XX Teahouse with my son. She replied, "I'm sure she can." I thought it was okay. I needed to work for 6 days and rest for 1 day; the lunch was also covered. The salary was so-so. Then I became a waitress here, leading the guests to their seats and carrying plates. This was my second job.

I worked all day long for 6 days every week. That was really hard. I felt I couldn't carry on any longer after a month. Also, an accident happened during working hours. I was wearing a pair of black shoes and I was carrying bowls of soup, when suddenly I slipped and fell on the stairs in a narrow area. The soup spilled, and my legs got seriously burned and turned red.

My husband also worked there at that time after I made an introduction. When the accident happened, he was also on duty, so he took me to the hospital. My son was at home with his grandparents. Normally, it doesn't matter if you break something at work, but you need to avoid hurting people. I was just so unlucky... The company didn't provide any compensation, but simply reimbursed my expenses in the hospital. 
I rested for a month at home. I thought the work was really exhausting, so I quit. In total, I worked there only for a month.

I actually had a great time at the XX Teahouse. In the beginning, we seldom talked as we didn't know each other well. Gradually, our manager and head waiters took really good care of me. I felt a bit embarrassed as we were of the same age. The manager just acted like my elder sister, saying that, "Just tell me if something makes you upset. Is there anybody who treats you badly?" I would reply, and tell her that I felt I wasn't capable. Ms. Zhou, the manager, said, "Don't look at it like that. Sometimes, it may be your illusion. No one looks at you differently. If you want to quit, just tell me." Occasionally, I might think too much, trying to pursue perfection. She was off duty on the day I got burned. Later, she was told by the head waiter that I spilled the soup. Only she knew I had the disability certificate. So, working there as a normal person in the eyes of other staff, I felt pressured due to their constant care.

After I left the XX Teahouse, I rested at home, took care of the baby, and found another job at X Home when my son was 1 year old. This was also introduced by my ex-colleague. At first, I read what she posted in the WeChat moments. I found that this was a German brand selling home décor for the balcony, like the spider plant. I thought it looked nice, so I asked my ex-colleague if they still recruited people. I also checked on their website and walked around in their shops to get a general picture. After all these, I considered it wasn't that hard. I needed to work for 5 days and could rest for 2 days. After being recruited, I was assigned to the branch in Shan $\mathrm{X}$ Supermarket, with an exhibition stall setting up at the gate. Every day, I sold goods and restocked. It felt okay. There were also morning and night shifts. The manager cared about me. She knew about my situation, and told me, "You're not that good at attracting customers and persuading them to buy our goods, so we decided to assign you to our experience store."

The experience store is located at Yanjiaqiao, near the Youxiang Furniture company. It's on the first floor of a building near our office building. I was so clumsy that I couldn't drive the electric vehicle. Normally my husband took me to work and picked me up. There weren't many customers. Most of the people in the building went to work here, including some of our company. The environment was okay. Just somewhat remote and old-style.

The experience store aims to show customers the products, the layout, and the design of a balcony. I also sold things there, introducing items to clients occasionally. I only succeeded in one deal when a regular customer came. The competition wasn't so fierce when I worked at the XX House previously. Except when the manager and some top heads came to visit, I was the only staff member in the store. Every day, I helped report the performance of Shan X branch, summarized the day's work, and planned for the next day. I also needed to do some cleaning. That's all. It wasn't that hard.

There were many departments in this company, such as the design department and $\mathrm{HR}$, and so on. All the colleagues worked in offices. As I went to work in another building, and only had the chance to meet and talk with my colleagues at lunch, our relationship was kind of distant. When I was at the XX House, colleagues were closer, like friends. We ate together, hung out, and took care of each other. In this 
company, however, they didn't know about my real situation, and I couldn't talk too much for fear of exposing myself. So, our relationship was more distant. Sometimes I had lunch alone.

Later, the company opened up a branch near the Shan X Supermarket. Colleagues working at the exhibition stall were reassigned there. They might ask me to prepare things, do invoicing, and fill in for some colleague who didn't come. It was good. Colleagues here only talked about work, not personal life. They didn't have many personal friendships. The colleague who brought me in was of the same age as me. She's also a mother now. We aren't that close currently, but she got along very well with other colleagues at that time. So I thought, whatever.

I was outgoing at work. After I got familiar with everything, when colleagues asked me for something or an answer, I told them I had a treasure box. You named it, I gave it to you. The communication with colleagues was just okay, not that intimate. I thought it would be enough that I handled all the work. If there was nothing to do, I just had a rest.

At X Home, no one knew I had the disability certificate in the beginning. But the colleague who brought me in told the HR department about it, as the company could enjoy some benefits with this. ${ }^{6}$

I enjoyed working at the exhibition stall at the gate of the Shan X Supermarket. It was just that I got quite busy during weekends. Then somehow, my colleague started to ask me about my disability certificate. I said it was about to expire and I didn't know how to renew it. Then this colleague told our manager, who later tried to persuade me, "Lele, are you a disabled person? Do you have a disability certificate?" I said yes, but it expired. Then she said now that you had it, go to the subdistrict and renew it. I replied I'd ask my mother-in-law. After listening to my sudden inquiry, my mother-in-law wondered why. I told her what happened in the company and said actually I didn't want to renew my previous certificate. So I replied to the company, saying that, "Sorry, I'm afraid I may not be able to renew it. My household is registered in the Hongkou District as a collective one. All my files are kept there." They thought about it for a week, and came to ask me again, I still said no. In the end, the manager came to me, asking me to check around when I was off duty to renew the certificate. It was so annoying. I went to the Hongkou District many times. Also, the certification of my collective household registration was only valid for about a month, I had to go to the police station to renew this as well. My mother-in-law accompanied me here and there, which was exhausting. In the end, we called the DPF. They told us we could go to an office in Pudong for registration. The files were also kept there. We finally succeeded. Then the company copied my certificate.

Q: Did this affect your work later on?

Xing: Of course. My sales capacity was thus affected. X Home focused a lot on your performance, namely your ability of promotion. Previously, though I didn't sell

\footnotetext{
${ }^{6}$ This benefit refers to policies concerning corporate income tax preference, subsidies for employment of the disabled, and the exemption of corresponding proportion of employment security funds for the disabled of the employee concerned, to encourage recruitment of disabled staff.
} 
that much, I could still participate in the meetings with colleagues. But gradually, due to the certificate thing, everyone knew that I was a disabled person. This made me feel pressured. Why did it become like this? Our manager said, "This is no big deal. It's nothing shameful." So, I didn't complain about it. Later, my supervisor thought I wasn't a good saleswoman, and assigned me to the experience store, as I mentioned earlier.

I knew a deaf-mute person during my work here. She was in her thirties; we were both disabled people. She worked at the reception of the HR department in our office building. I could see her at work face-to-face as the two buildings were next to each other. Every day, she came for invoicing and wrote something on the blackboard. She was quite good at doing some practical work, but she couldn't hear. When you communicated, you could only type, or ask her to read your lips. When we talked to each other, if she didn't understand what I said, she would definitely ask me again. As we were similar, we were somewhat closer, but we still remained just colleagues. The majority in the company didn't know about our situation. Some administration and HR staff might know; they must have reported this to the boss.

Q: Do you have any goals in terms of work?

Xing: We may not be able to get a promotion, but all I want is a year-end bonus or social insurances, as our monthly salary is fixed. I once heard that the company provided New Year dinner and this kind of bonus. I started working here in February 2016, around the Spring Festival. So, by next February, I will have been working here for a year. I might find out if I get the bonus by then.

We don't talk about the salary in the company, as it's confidential. When we get the salary sheet, we just check for ourselves, and ask HR if there are any questions. I earn about 3,200 yuan a month after tax deduction.

Q: How do you feel after experiencing different jobs?

Xing: I felt at ease working at the XX House. The older colleagues would take care of me and there were more Shanghai locals. I felt quite happy.

At the XX Teahouse, there were fewer local people. It was more tiring. When there were many customers taking orders, it could be quite busy, especially during lunchtime. I just couldn't keep up with the pace. Though the managers didn't blame me, I would feel bad and frustrated myself. It was uncomfortable and exhausting. I could only rest for 1 day and work for 6 days. I couldn't stay at home for long.

At X Home, I work from 9:30 a.m. to 6:30 p.m. for 5 days, and rest for 2 days. Sometimes I may get off late, but there isn't actually any customer. Besides, in a company just next to me, people work from 9 a.m. to 5 p.m., then there's no staff in the building, either. I think I can just muddle along and see.

Teacher: The XX House is among the enterprises recommended by our school, in addition to Starbucks, InterContinental Hotels, and Novotel Shanghai Atlantis. We visited all these companies, and considered their environment, inclusiveness to our students, and their preferential policies of recruiting disabled persons, before we recommend them to our students. We need to be responsible for our kids. Her current workplace has nothing to do with our school, so we don't know what it's like.

After 2 or 3 years of work, many students have changed their jobs, which is also beyond our reach. We don't have enough capacity to help them throughout their 
future life. Luckily, Le Xing always contacts me, so I can remind her about important considerations at work. First, social insurances; second, welfare and bonus, monthly salary; third, inclusiveness of the environment and discrimination. They must bear these in mind, before they can make a living by themselves.

I think her capacity is improved after she worked at the XX House, XX Teahouse. Now, she can even find a job on her own. Every time when she wanted to resign, she would tell me about it and ask my suggestions. I told her, "Think before you leap. You can do so if you know what your next step is." Teachers and parents should allow our kids to adapt themselves to society, experiencing the reality, with both the good side and the bad side. When she got burned in the second job, she also told me and said she wanted to quit. I agreed, telling her personal safety still mattered the most. After she gave birth, she wanted to go back to work again, I encouraged her to go ahead if she had really thought it through. Though the job people can do is related to their ability, I think it has successfully contributed for Le Xing in becoming who she is today. Her current state of work and life is really impressive.

Xing: Normally I don't ask for teachers' help. I try to find a job by myself.

Sometimes I want to change jobs, but I can only sell things, since I don't have the qualification for administrative work or a diploma. I don't rely on teachers a lot, but I'll talk to them if I feel unhappy and bored. My teachers may ask me how my work is and whether I get along well with my mother-in-law, I say it's okay. I still think the XX House was better compared to other companies. Currently, though the colleagues are about my age and communicate well, I still feel different from them, thinking that they're more capable.

Teacher: She loves chatting with others, especially when she's free. But actually, we're quite busy. So sometimes, I told her, "I'm too busy to chat with you. Now that you have become part of society, you need to treat others sincerely. That's true. But you also need to know that there remains a suitable distance in interpersonal relationships." For kids like her, I also taught them some skills in terms of communication with others. I said to her, compared with the meagre salary of cleaning ladies, you already had a decent job and a good working environment.

Xing: There was a cleaning lady in my previous company. She came to work every day and also rested on the weekends like us. She was quite busy actually. That was why my teachers said I already had a good job with a satisfactory salary, and asked me to carry on, since finding jobs could be really hard. We're not that competent. Even if I want to be an office lady, I'm bad at typing and I don't have a good memory. Also, the working hours are basically the same everywhere. Gradually, I came around to the idea. Occasionally I may get narrow-minded in life, but now I've made some progress.

(During the two interviews, Le Xing was fired.)

Q: Did the company inform you of the layoff in advance?

Xing: Not at all. I was informed on the same day I was fired. The deaf girl and I were the first two people fired. In the afternoon, the deaf girl said, "I want to tell you something. I was fired." Later at 6 p.m., HR sent me a WeChat message, asking me to go to the meeting room. And I was told that, "Lele, you must have heard that we're laying off people recently. I'm sorry." 
I think they didn't tell me the real reason. They just made an excuse, saying that the boss thought there were too many staff and my department no longer existed. As I'd signed a contract with them, they'll compensate me with some money, given to us together with the salary on December 20. In our company, the strange thing is that in a particular month, we not only receive the salary of the month before, but also that of this month. Sometimes, the finance staff also make mistakes. I started to work here on January 18. On payday, I should only have received salary for 2 days, but I got 3,200 yuan surprisingly. My mother-in-law also said that was quite a lot of money. By the time they fired me, they discovered this mistake, so the extra part will be deducted from my December salary, and my overtime payment for October 2 and 3 will be added to it. All in all, it's a total mess.

Q: How much can you get as compensation?

Xing: Two months of salary. My pre-tax salary is 3,500; net income is about 3,200 or 3,300. This is okay, since meals are also provided by the company. Unfortunately, I have to return the 3,000 yuan given to me by mistake as I just mentioned. It's ridiculous. I received all the salary sheets through email, how do I know how they calculate the money? Though I only worked for 2 days, the email showed that much money, then that should be my money. No one made it clear to me until now. My mother-in-law also felt very angry about it, but she decided to let it go. Actually, the finance staff have made many mistakes. Once, they even asked us to return the money delivered by mistake. Considering all these, my mother-in-law always reminds me to be clear about the money.

$\mathrm{Q}$ : Is there extra subsidy provided by the government apart from the income at work?

Teacher: No. The government provides subsistence allowance to the severely disabled people who can't work, but Le Xing is mildly disabled and employed, so she doesn't have that. This is the policy. I think the mildly disabled also deserve some, but there isn't. If these people aren't employed, they won't have social insurance, which means that they have no financial guarantee after they retire or when they're old. Idleness does them no good, either. The subsidy of about 1,000 yuan is never enough for their daily needs. It's better that they go to work if they have the chance, which enables them to communicate with others. Now I think that this young couple really lead a good life. They have jobs, they have their child, and they can become more mature in their social interactions. What's the point of staying at home? They're still so young!

\section{Happiness Lies in a Simple Life}

Q: Do you have any other concerns in life? What expectations do you have for the future?

Xing: I'm worried that my son may not be able to study well. But we can only send him to the school. My mother-in-law once said that both my husband and I had difficulties in learning, so we never knew how our son would develop in the following 
year, as kids grew fast. I also see many of my colleagues attend the parents' meetings at school. I worry that if I attend such meetings one day, what if I can't understand the teachers' words? I simply hope that my son is healthy, this is the priority, and smart. We'll support his studies as long as he can keep up with the class. We hope he can make many friends with other kids. I wish him all the best. That's all. In the family, I hope everyone can be happy, and talk with each other if there are any problems.

In terms of work, I have no expectations. Sometimes, I envy those colleagues who're close and eat together, since I'm alone. But the important thing is, I just need to do my work well. That's enough. As for friends, I once asked Ms. Yang of the dancing team to organize a party, but everyone was busy at work. I work from Monday to Friday, while some others may work on weekends. So, we couldn't get together. What a pity! Now I just go back to school occasionally. My in-laws told me that, "It's not that good if you visit school too often. After all, you already graduated and have a family. Don't go there bothering other people."

Teacher: Don't worry too much. Everyone goes through this when they grow up. Your current life is really good, right? Nothing bad happens. Simplicity is also a kind of happiness. Sometimes, I really envy her. She's strong, optimistic, and always enjoys herself. Just remember to cherish what you have now.

\section{Interview with Le Xing's PE Teacher}

\section{Interviewee: Ms. Zhuoying Shi (PE teacher)}

Interviewer and writer: Jing Zhang

Interview date: December 17, 2016

Interview place: School of Special Education in Pudong New District, Shanghai

\section{Teacher's Confidence Boosted Thanks to a Promising Student}

Q: Could you please tell me when Le Xing caught your attention?

Teacher: During my PE class after she entered school.

Q: What exactly attracted your attention?

Teacher: She looked like a boy with short hair when she was little. I thought she was a boy at first, then I discovered I was wrong, I became interested in her particularly. She's quite flexible.

Q: When did Le Xing start doing gymnastics?

Teacher: Quite early. It was around 2002 or 2003, when she was in the third grade. When our school started to add the gymnastics course, I invited her to practice with other kids together.

Q: I heard from Ms. Wang that you were the main coach of the gymnastics team.

Teacher: Previously, there was no gymnastics in our school, just table tennis, track and field, etc. 
Q: How did you think of the idea, involving students in gymnastics?

Teacher: We got to know that there was this new event in Special Olympics. In addition, gymnastics is really helpful in strengthening their body in all aspects. Different kids have different weaknesses, either in strength, flexibility, or physical coordination. Therefore, previous group events may not be suitable for everyone, but gymnastics allows for individualized exercises and enables each student to bring his or her strong suit into full play. Le Xing, for example, can avoid her weakness in basketball.

Q: Did you ask all the students to practice gymnastics or did you select some people?

Teacher: There were many, actually. We had the morning exercise, basically all of her class came. We didn't start from gymnastics moves, but with some simple exercises, like stretching the legs, bending the waist, and doing the splits. We didn't have much equipment back then. It was just some exercises.

I once trained a team of six girls in rhythmic gymnastics in a regular school, so I did the same here, teaching Le Xing and other students the group free exercise, and starting from the basics, like stretching the legs.

This group of girls, including Le Xing, was the first "gymnastics team" I coached. We started our training before we ever took part in competitions. We stretched our legs on railings, kicked, bent our waist, and did push-ups. In case of a competition, extra training was added based on the specific moves, like ball routine or ribbon, etc. Initially, we only knew we should enhance the basics, including strength, flexibility, and coordination, then we decided on specific moves for further practice.

Actually, Le Xing was the one who encouraged me to carry on in the beginning. Every day, I asked all the students to lean on the wall, and hold up one foot to stretch their legs. They felt it hurt and it was boring. When we moved on to the ball routine, most kids flinched from it. What should I do? Of course, now that we've experienced many games with good results, I can tell students that we must work harder, instead of being complacent. But back then, we started from scratch. We never knew when or if we would ever compete, nor did the kids make much progress, as the moves designed for normal students were kind of hard for them. Eventually, only Le Xing was able to do half of the whole set.

Q: They didn't get it?

Teacher: No. Maybe the moves were difficult, and they couldn't carry on. After Le Xing learned half of the moves, there was an event in the school. I asked them to have a performance together, but no one dared to do it. At last, Le Xing went on to the stage.

Q: She performed alone?

Teacher: Yes, only her. Others weren't as good as her. She needed to roll the ball on her body while doing all kinds of moves. The show was quite a success. Teachers praised her; other classmates admired her; she herself became much more confident. This boosted other students' confidence, as well as my own. This performance attracted five other girls. Then the six of them kept practicing, later becoming our gymnastics team. They even performed the ball routine on TV. 
At that time, we didn't know about the events in Special Olympics. Later, when we learned that gymnastics was added, we wanted to go, and received some simple training on parallel bars. Before this, our girls only practiced with balls.

Q: You've always been coaching Le Xing?

Teacher: Yes. Ever since the gymnastics team was established, all of us PE teachers trained them. Now we have a better division of labor. Some other teachers are training students in other campuses.

Q: Did Le Xing and other students supervise each other?

Teacher: Yes. Seeing others outperforming her, she would feel pressured and worried. She had her own goal to practice well, compete with others, and win medals.

Q: You've been coaching the students, so you did more than other teachers, right?

Teacher: I came earlier than other teachers for the morning exercise. In case of competitions, there would be extra training. I was willing to do all these. It wasn't a burden for me.

Q: It was you who demonstrated the moves to them?

Teacher: Sure. I either learned them from the beginning by myself, or together with them. At first, they might not have been able to understand the video, but gradually, smarter students began to get it, until all of them became better and better.

Q: Did the gymnastics team go through hard times?

Teacher: Of course. It was really tough. We started from scratch, with no equipment and no video tapes. We did it all by our own, step by step. Gradually, the school supported us with equipment, and training outside. We went through ups and downs. Sometimes I felt it was pointless, especially when everyone reached the bottleneck without any progress...But this could happen.

Q: So, you not only trained the students, but also cheered yourself up along the way?

Teacher: Yes, that's true. When we started training, we didn't know when there was going to be a competition. Even if we knew later that one would be held in 2007 , we had no idea about who were the players and what the game was like. But I've always been highlighting one thing to all the team members: whether you could go to the games or not, exercise was for your own good. For some kids who couldn't compete, I would tell them that, "You performed really very well. You can put on a performance with other kids at school."

The first step is always difficult. If we gave up midway and only started practicing gymnastics in the 2007 intensive training, then we wouldn't be able to stand out, as no solid foundation would have been built, and we wouldn't have had the chance to compete again in 2011. In the 2007 Special Olympics, the nine athletes of the Shanghai team ranked among the top. One of the boys even won seven gold medals. We could perform better than the other teams, simply because we started earlier, worked harder, and persisted in stretching and practicing every day. We had a solid foundation. That was why our team was able to be part of the 2011 games as well. I owe all these achievements to the hard efforts of the first members, including Le Xing.

Q: Now you still tell kids to focus on physical exercises? 
Teachers: Yes. I tell them that exercise always comes before the competitions. Of course, it can be good if we perform well, win gold medals, and make new friends, but only a few of the ten kids have the opportunity to compete in the games. Some kids and their parents might feel unhappy about this; some others just give up. From our perspective, as we need to achieve something during the competitive games, we won't choose those who are lazy or weak or whatever. Even Le Xing might slack off occasionally when she was exhausted.

Now as our gymnastics team grows bigger, not everyone can have a spot for morning exercise in the original room. In response, I just provide some basic sessions; students who are particularly interested in gymnastics can receive further training. In PE class, I also try to introduce a bit of my idea. We don't have to take part in Special Olympics as gymnasts, but this sport is definitely the foundation. At least, it's beneficial for the body, and girls can build up a beautiful figure. Other teachers agree that gymnasts stand straight and look good.

\section{Special Olympics After All the Hard Effort}

Q: Did your team ever participate in other games before the 2007 Special Olympics World Summer Games?

Teacher: Sure. We attended a national competition in Tianjin in 2005, and the national gymnastics competition for children with special needs in Changchun in 2006, when I asked Mr. Zhang from Taiwan about the gymnastics routines in Special Olympics and started to learn from a video disc.

Q: You've been the coach during this whole process?

Teacher: Other PE teachers also help me. I myself am not a gymnastics teacher. I only had some experience in a regular school. Therefore, guidance from professional coaches is often needed.

Q: When did you start to invite other people to coach?

Teacher: After we finished practicing the ball routine, we still hoped to take part in competitions, so we first learned from discs. The founder of Special Olympics, caring about the gymnastics training in our school, provided guidance in person once. Some of my ex-colleagues from an institute of physical education also provided professional guidance several times. I turned to these people for help in the beginning, as I didn't know much myself.

After we started attending competitions, we got to know many people from the physical education school, and professional judges and coaches. Sometimes, the school applied to have several training sessions in professional gymnastics rooms. There weren't a lot of resources at first.

In 2006, Shanghai held an invitational tournament, with several participating teams, including Russia and Hong Kong SAR. There was still a Shanghai team at that time, while our school represented the national team, of which Le Xing was a member. We were widely involved; all the PE teachers received training. After the tournament, the professionals confirmed our strengths, while pointing out where we 
could do better. During practice, I felt it was already enough when students could do the moves, but the coaches paid more attention to details, like postures and straight legs. That's where the beauty of gymnastics lies. An international judge whom we met when he worked as the deputy judge in one tournament often provided guidance to us in our school as well.

Q: He's a Chinese?

Teacher: Yes. Foreign judges can only come occasionally.

Q: So, the gymnastics team got on the right track after Special Olympics?

Teacher: Yes. Special Olympics brought our team to everyone's attention. Our members were known, advantages recognized, and disadvantages pointed out. As the 2007 tournament was of particular significance at the national level, we were able to attend the intensive training in Tianjin. Gymnasts were also classified in the national team as Level 1 and Level 2 with an increasing level of difficulty. Le Xing belonged to the latter group, together with several other outstanding kids. At this stage, training sessions were divided based on specific events. Le Xing competed in artistic gymnastics, like uneven bars. It was harder, and Le Xing was really hardworking.

Q: Le Xing chose to practice artistic gymnastics, or you assigned her to it?

Teacher: I assigned all of them. Some kids were timid. One girl, for example, didn't dare to practice the uneven bars after one fall. Rhythmic gymnastics is relatively less dangerous and difficult. It focuses more on the beauty in motion.

Q: How many students did artistic gymnastics?

Teacher: In our school, only two girls. Initially, I required all students to learn both artistic and rhythmic gymnastics. In the Shanghai team, there were about five or six other kids doing artistic gymnastics. Though only six kids went onto the stage, more kids actually practiced together, as there were fewer intellectually disabled students back then. ${ }^{7}$

Q: You led the team to Tianjin for intensive training?

Teacher: I took our school's team there. After we started training, I was responsible for rhythmic gymnastics. We lived together, though. Several professional coaches were also invited to join us.

Q: What did you do during the intensive training?

Teacher: Mainly the basics, the moves. We had reached the basic requirement of all the moves at school, so our main goal in Tianjin was to improve the quality. There were assigned rooms and professional coaches. We trained for 3 months.

Q: All of you stayed there for 3 months?

Teacher: Yes.

Q: It was really intensive, right?

\footnotetext{
${ }^{7}$ According to Article 19 of the Compulsory Education Law of the People's Republic of China, implemented on September 1, 2006, regular schools shall admit to the classes disabled children and adolescents corresponding to the levels of the disabled's school-age, who are capable of receiving regular education and provide them with aid in study and rehabilitation. In addition, as the concept of inclusive education becomes popular, more and more children with mild disability are admitted to regular schools; students in special education schools are of a higher disability level.
} 
Teacher: Indeed. When everyone stayed at the hotel, I would supervise their exercises. They just couldn't stop, otherwise, their flexibility, and strength, would deteriorate over time. I monitored them every day, asking them to stretch their legs even when watching TV.

Q: Were all of Le Xing's classmates at basically the same level?

Teacher: Le Xing was relatively more intellectually disabled. When she became involved in Special Olympics, we provided her with many opportunities, like hosting a ceremony, or acting as the Special Olympics leader. Nonetheless, she was still timid, feeling afraid of such an event. Later, Qiao Li, one of her classmates, became the hostess in many events.

Q: Le Xing already attended some activities before the 2007 games?

Teacher: Yes, but it still didn't work. She was shy and timid, and tended to stammer.

Q: What do you look at when you select students as the Special Olympics leader or to attend events?

Teacher: Generally, we encourage them to participate as much as possible. They all love to be part of the various PE activities. We mainly consider their strengths and characters and identify the suitable activities. Qiao Li, for instance, is better at expressive skills. Some other kids may be good football players.

Gymnastics also has several levels. Simple exercises were suitable for everyone. After we had formally set up the Special Olympics gymnastics class in our school, we tried to provide every kid with access to events and competitions. Based on the level of difficulty, gymnasts would compete in Level 1, 2, or 3. So we chose the best ones at each level, instead of sending all kids at Level 3 to the games.

\section{Gold Medals Thanks to Persistent Learning and Exercising}

Q: During the training, did Le Xing stand out?

Teacher: Yes. She was the first to perform, and it was her first performance ever. Though she felt afraid, she still presented tremendous courage. I comforted her, "It doesn't matter. You already outperform the other kids at school." Actually, her performance wasn't even a complete set of moves.

Q: She performed well because of her capability or something else?

Teacher: She was hardworking and careful. She also pushed hard when helping others to stretch the legs. Sometimes, I might assist her when she stretched her own legs, as it could feel sore. Difficult moves, like rolling the ball from one side to the other, require repeated practice. Some kids might have stopped when they couldn't make any progress, while Le Xing just kept on trying.

Q: Was Lele interested in the gymnastics herself, or you supervised her?

Teacher: I supervised every kid, but she made the biggest effort.

Q: Did she ever complain and want to quit?

Teacher: Occasionally. She could carry on for most of the time. After all, she was only a kid, just trying to get attention (laughing). Overall, she was excellent. All the team really put in a lot of effort. 
Q: Did she get along well with other teammates?

Teacher: She could help others. We had younger teammates and some with Down syndrome. She took care of them just like a sister. Sometimes she also helped me clean the floor if she saw me doing it in the gymnastics room, for example. Students back then were thoughtful. Sometimes she felt depressed due to family affairs, but later, she became more open after taking part in many activities.

Q: Did she ever make mistakes and make you angry?

Teacher: She made mistakes once in a while. It was normal.

Q: Was there anything impressive?

Teacher: Her perseverance. As I mentioned before, a girl fell from the uneven bars and stopped training from then on. Lele was scared and affected of course, but she didn't and wouldn't give up.

Q: In what respect did Le Xing perform well in terms of gymnastics?

Teacher: Since she was hardworking, she could handle the difficult moves, like a single move of the floor. But when she performed a whole set, she tended to be faster than the rhythm and beats of the music. As such, she needed to practice again and again, which was quite boring. It made her worry.

Q: Did you have some expectations or set some goals for everyone, especially Le Xing, before the 2007 Special Olympics?

Teacher: During training, I told them that now that we are taking part in the competition, and in different events, we must strive to be the best in our own event and win the gold medal. Otherwise, no one would have the motivation. During the final games, scores could be deducted due to details. What we could do was to practice, practice, practice, and strive for our best, like trying to get 10 points in rhythmic gymnastics, as we never knew about other people's performance. Just ignore others. That was what I told them. This way, the training could be really tough and boring.

Q: Were you satisfied with everyone's performance in 2007 ?

Teacher: Of course. They were unexpectedly excellent, winning many medals. I was really optimistic. I always reminded myself not to expect too much, so that I wouldn't get disappointed. For these kids, encouragement and the process matter more than the result. One girl felt really frustrated and disappointed as she only got silver ones, and most of the other teammates won gold medals. This showed that the performance of our Shanghai team really ranked among the top nationally.

Q: Was Le Xing's performance the best among the kids?

Teacher: There were other girls winning five gold medals. She won three gold and two silver, which was good as well, as she competed in a more difficult event. My expectation was solely medals, whether it's gold, or silver, or bronze. Winning them, especially gold medals, was never easy when competing with so many athletes.

Q: After the 2007 Special Olympics, Lele got more chances to participate in activities, right?

Teacher: There were indeed many events, but Le Xing might not have been as talkative as Qiao Li.

$\mathrm{Q}$ : Was there any change after she won the medals? 
Teacher: The sport made her happy and had a positive impact on her work. She once told us that she didn't feel tired after standing a long time at work, thanks to all the training and competitions.

Q: What other competitions did she take part in between 2007 and 2015 ?

Teacher: She also took part in an aerobics competition in Shanghai after the 2007 games. As the team from our school performed the best, we were assigned the task of aerobics choreography for special education schools in Shanghai. She was involved in it as well. That's all. In 2007, she went to the vocational department.

Q: There was no gymnastics class in the vocational department?

Teacher: No, but there were dancing and other courses.

Q: Apart from gymnastics, she also danced?

Teacher: Yes. Gymnastics and dancing are complementary; many basics of the former could be reflected in the latter. She was taught dancing by her music teacher and performed outside the school many times.

Q: When did she start to work?

Teacher: She went to the vocational department in 2007 and started to work in 2009 or 2010. From then on, she was kind of busy with personal affairs, like her relationship and marriage, plus we had six other athletes, so I didn't invite her back. There was also one competition held in Greece in 2011 when she still worked and just gave birth to her son. I guessed she was busy, so I didn't ask her about it, either. Later she asked me why I didn't invite her or things like that. She liked the competitions, so she always wanted to be part of it.

Q: Then why did you decide to invite her to the 2015 Special Olympics World Summer Games in Los Angles?

Teacher: It's because we were really close and stayed in close contact. We considered this orphan as our own kid, while she called us mother, and invited us to her wedding ceremony and baby's birthday. She still came to visit us at school after she became a mother herself, so we told her about the competition. She really had the willingness and initiative, and starting training at school soon afterwards.

The 2007 Special Olympics had more participants. We sent several teams, including the rhythmic gymnastics team with ten, and the artistic gymnastics with more than ten athletes. By 2015, the number of contestants going to Los Angles decreased. All the athletes were students selected from our school, instead of all over China. We established the team on our own with me being the coach. I didn't have enough energy back then, so all the four girls competed in rhythmic gymnastics.

Q: Was there intensive training before going to the US as well?

Teacher: We just exercised in the gym of our school. During the summer vacation, we temporarily practiced in the gymnastics room in another school before the games. One coach was invited to train the boys, while I guided the girls. The focus was to improve quality.

Q: The level of difficulty was also increased during training?

Teacher: Definitely. Though Special Olympics emphasizes participation, competitions still focused on the quality of your moves, after all. We must try to make progress in every move. Le Xing practiced artistic gymnastics very well, but this time, she had to start from zero, namely, Level 1. She was kind of stiff and couldn't 
follow the rhythm, so I always corrected her... This repeated exercise made her upset and anxious.

I told her not to get worried as we still had enough time for training. We could divide the moves and do them step by step while following the beat. If she was too tired, I'd chat with her, and ask her to do some other moves that she was good at, or perform a handstand and a backbend to other younger teammates. This helped in refreshing her. She also knew to learn from other students who were better than her, and always listened to the music I sent her with her phone.

Q: She was new to rhythmic gymnastics and she just had a baby. What was your expectation towards her this time?

Teacher: She demanded to come here. Sure, I had some expectations, but she was also really strict on herself. As she had won gold medals in 2007, she still strived to achieve this goal in 2015. Therefore, she felt anxious, worried and pressured about what would happen if she couldn't win medals due to mistakes or bad performance. She pushed herself hard ever since the start of training, while I tried to comfort her and ask her to take it easy.

Q: What did you think of her performance in Los Angles in 2015?

Teacher: Surprisingly excellent. She won five gold medals, outperforming all the other teammates.

Q: She performed so well simply after training for such a short time.

Teacher: On one hand, the challenges for her were that she had stopped training for a long time, and that she actually needed to start from zero, adapting to the new requirements of rhythmic gymnastics. On the other hand, she competed in Level 1 this time, which was less difficult. Her years of training also laid a solid foundation. So generally speaking, she was really a well-qualified athlete.

Q: In what events did she win the gold medals?

Teacher: Ball, hoop, ribbon, rope, and all-around. She won all the five gold medals accomplishing her own expectations, making her wild with joy. But during the training, she was still anxious as she tended to be either faster or slower than the rhythm. I constantly corrected her.

\section{Growth Under Teachers' Care}

Q: Were there any problems that gave you a headache during her growth?

Teacher: Kids in her class tended to act freely, doing whatever they wanted. Either it was me who took them to activities or training, or their music teacher went to performances with them, some of them might just go somewhere else on their way back home. This occurred frequently.

Q: Where did they go then?

Teacher: They just didn't want to go home. Some might wander around their community, some might date their boyfriends or girlfriends, some others had tensions with their families. One girl, for example, always felt sad due to things like being beaten by her mother. Le Xing had similar issues. 
Q: Would she tell you about it?

Teacher: Yes. Her foster mother once even came to our school, waving her shoes and threatening us not to mess with her during her menopause. Perhaps she felt upset as a single mother with two kids, her own son and Le Xing. Though we talked with her mother, we mainly persuaded Le Xing, and another foster girl who often stayed out all night with her, to behave themselves, to appreciate the effort of their mothers, not to make their mothers angry, and told them that they needed to rely on their own when they become adults. We communicated with them a lot.

Q: Did Le Xing do as you said?

Teacher: Sure. Though she was angry when her foster mother beat her sometimes, she was obedient in general. There were unavoidable issues. What we could do was to take better care of her and take her out to have fun.

Q: You were also concerned about their lives, right?

Teacher: Yes, it's true. Some students weren't treated well at home. A girl wasn't able to take a shower, so we helped to wash her body; another student might not be able to study in the evenings since the parents turned off the lights; other kids might even be asked to collect garbage. That was mean. All the miserable girls talked and sympathized with each other. Lele was among them because of her mother, but we tried to let her know that it wasn't good for girls to stay out like this.

Q: How did you normally help her regarding her everyday life?

Teacher: I would ask her about her meals, like whether she had had her breakfast before training, etc. Her mother did well in this respect. In addition, when her mother was angry, or beat her with the heels of her shoes, she might become upset and talk back. I would teach her to give her mother a massage and communicate more properly. Basically, she was obedient, doing the housework ever since she was little. This was also a necessary experience for her.

Q: Do you think she gained her capacity from home or school?

Teacher: It's both. Our school provided education and guidance. Her mother also did her part by asking her to do housework. We're not saying that children should do nothing, but Le Xing might have done a bit too much. She was a foster child after all.

Q: How were her studies?

Teacher: Her IQ wasn't among the best in her class; especially in terms of memory, logic, and numbers, she was probably below average. During training, she also had extra lessons, and came to me for help. I would ask her about her studies, and told her to work hard and study, otherwise training would be discontinued.

Q: It seemed that she liked training a lot.

Teacher: Yes. Maybe due to the environment of her foster family, she really looked forward to and enjoyed participating in training and all kinds of Special Olympics events.

There were cases where students had to leave our school as the parents decided to stop fosterage. One kid from the welfare center had to transfer to another school, while another girl, who was as hardworking in training as Le Xing, had to stop training because her foster mother thought she wasn't smart and kicked her out. So, we always reminded Le Xing of the good side of her mother, who actually raised 
her. "What if she wanted to return you to the welfare center? Then you would have had to leave the school," we said. We comforted her and asked her to behave herself at home. After all, there were things that we couldn't control.

Q: Would you communicate with her mother?

Teacher: I seldom did this. The teacher in charge shouldered more responsibility and might have talked with her mother if they met. The mother's temper was kind of...

Q: Le Xing said her mother sometimes came to the school. Was this true?

Teacher: Yes, her mother normally went to talk with the teacher in charge.

Q: Was that Ms. Cai?

Teacher: No, it was Ms. Wang. Ms. Cai usually took Le Xing to various activities, like the Special Olympics Global Youth Leadership Forum. All of us teachers took great care of the students, especially those from the welfare center, as they received less care at home. We just treated them as our own kids.

Q: Le Xing told me that apart from you, Ms. Cai also looked after her throughout the years. Could you tell me about it?

Teacher: Before 2007, Ms. Cai took the students to all kinds of events, including acting as unified journalists, while I coached them in gymnastics competitions. Later, Le Xing rarely took part in events. In 2015, she was quite successful as the hostess in a charity gala dinner. She became more mature with experiences in other activities.

Q: What about the scale of the dinner?

Teacher: It was the Special Olympics Unity Fundraising Gala Dinner held by Special Olympics East Asia, inviting Mr. Shiyi Pan, Ms. Lan Yang, Mr. Ming Yao, other celebrities and the Special Olympics ambassadors.

Q: Why was Le Xing selected?

Teacher: I recommended her. I thought she could perform better in such occasions after experiencing many activities and working in different companies. Besides, the staff from Special Olympics East Asia helped her with the rehearsal.

Q: Do you think these events have influenced her growth in some way?

Teacher: Yes, she became more confident.

Q: Any negative impact?

Teacher: Not really.

Q: What kind of guidance did you give her after she graduated and started working?

Teacher: I would chat with her. She told me she was selected as the best member of staff, and shared with us the joy of her marriage and the birth of her son. I was also invited to her wedding ceremony, but I couldn't make it as I got a fracture back then. She still tells us about her life now.

Q: Do you still care about her family life nowadays?

Teacher: As I know both her and her husband, who studied at our school, of course I often ask her about her life.

Q: Do you really support this couple?

Teacher: Of course, as long as she's happy and they love each other. Her motherin-law is just like a real mother, treating her very well; she also has a baby now. So, her life is quite stable and full of happiness.

Q: What's your opinion of her and what's your expectations for her? 
Teacher: I wish she can be happy. Previously she came back to school and helped me in coaching many athletes. I would say, "Le Xing, I trust you with all these kids." She would complete the task very well, since she was as strict with herself as with other teammates. I hope that she can visit the school often and help younger students in doing gymnastics.

Translated by Min Cui

Open Access This chapter is licensed under the terms of the Creative Commons AttributionNonCommercial-NoDerivatives 4.0 International License (http://creativecommons.org/licenses/bync-nd/4.0/), which permits any noncommercial use, sharing, distribution and reproduction in any medium or format, as long as you give appropriate credit to the original author(s) and the source, provide a link to the Creative Commons license and indicate if you modified the licensed material. You do not have permission under this license to share adapted material derived from this chapter or parts of it.

The images or other third party material in this chapter are included in the chapter's Creative Commons license, unless indicated otherwise in a credit line to the material. If material is not included in the chapter's Creative Commons license and your intended use is not permitted by statutory regulation or exceeds the permitted use, you will need to obtain permission directly from the copyright holder.

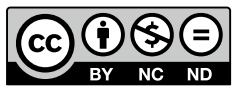

